\title{
Regulation and functional roles of sphingosine kinases
}

\author{
Regina Alemany • Chris J. van Koppen • \\ Kerstin Danneberg • Michael ter Braak • \\ Dagmar Meyer zu Heringdorf
}

Received: 1 December 2006 / Accepted: 22 December 2006 / Published online: 23 January 2007

(C) Springer-Verlag 2007

\begin{abstract}
Sphingosine kinases (SphKs) catalyze the phosphorylation of sphingosine to sphingosine-1-phosphate (S1P). Together with other sphingolipid metabolizing enzymes, SphKs regulate the balance of the lipid mediators, ceramide, sphingosine, and S1P. The ubiquitous mediator $\mathrm{S} 1 \mathrm{P}$ regulates cellular functions such as proliferation and survival, cytoskeleton architecture and $\mathrm{Ca}^{2+}$ homoeostasis, migration, and adhesion by activating specific high-affinity G-protein-coupled receptors or by acting intracellularly. In mammals, two isoforms of SphK have been identified. They are activated by G-protein-coupled receptors, receptor tyrosine kinases, immunoglobulin receptors, cytokines, and other stimuli. The molecular mechanisms by which SphK1 and SphK2 are specifically regulated are complex and only partially understood. Although SphK1 and SphK2 appear to
\end{abstract}

This review is dedicated to Prof. Dr. Karl H. Jakobs, who has guided the sphingolipid research at the Institut für Pharmakologie with his invaluable advice.

R. Alemany · C. J. van Koppen $\cdot$ K. Danneberg $\cdot$ M. ter Braak

D. Meyer zu Heringdorf $(\bowtie)$

Institut für Pharmakologie, Universität Duisburg-Essen,

Hufelandstrasse 55,

45122 Essen, Germany

e-mail: dagmar.meyer-heringdorf@uni-due.de

Present address:

R. Alemany

Laboratory of Molecular and Cellular Biomedicine, Department of Biology, Institut Universitari d'Investigació en Ciències de la Salut (IUNICS), University of the Balearic Islands,

Ctra. Valldemossa $\mathrm{Km} 7.5$,

07122 Palma de Mallorca, Spain

Present address:

C. J. van Koppen

Department of Molecular Pharmacology, N. V. Organon,

Oss, The Netherlands have opposing roles, promoting cell growth and apoptosis, respectively, they can obviously also substitute for each other, as mice deficient in either SphK1 or SphK2 had no obvious abnormalities, whereas double-knockout animals were embryonic lethal. In this review, our understanding of structure, regulation, and functional roles of SphKs is updated and discussed with regard to their implication in pathophysiological and disease states.

Keywords Sphingosine kinase · Sphingosine-1-phosphate · Sphingolipid metabolism · G-protein-coupled receptors

\section{Introduction}

Sphingosine kinases (SphKs) catalyze the phosphorylation of sphingosine, thereby forming the lysophospholipid mediator, sphingosine-1-phosphate (S1P; Maceyka et al. 2002; Hait et al. 2006; Taha et al. 2006a; Wattenberg et al. 2006). More than 30 years ago, the SphK-S1P pathway was considered as sphingolipid degradation pathway, as cleavage of S1P by S1P lyase leads to irreversible breakdown of the sphingosine backbone (Spiegel and Milstien 2003). Cellular signaling by S1P was first described in 1991 by Zhang et al. (1991). In 1993, Olivera and Spiegel reported that SphK activity and S1P production were regulated by extracellular mediators, namely, serum and platelet-derived growth factor (PDGF). Since then, our knowledge about S1P as first and second messenger has grown rapidly. S1P is now recognized as an important, nearly ubiquitous regulator of cell proliferation and survival, migration and chemotaxis, cytoskeletal architecture, cell-tocell contacts and adhesion, $\mathrm{Ca}^{2+}$ homoeostasis, and $\mathrm{Ca}^{2+}$ dependent functions. Many actions of S1P are mediated by specific high-affinity G-protein-coupled receptors (GPCRs). 
There is a family of five S1P-GPCRs $\left(\mathrm{S}_{1} \mathrm{P}_{1-5}\right)$, which have a high homology to GPCRs for the related lysophosphatidic acid (LPA), and three other putative, less well-characterized S1P-GPCRs (GPR3, GPR6, and GPR12; Chun et al. 2002; Anliker and Chun 2004; Hla 2004; Ishii et al. 2004; Meyer zu Heringdorf and Jakobs 2006). S1P-GPCRs play a role in vasculogenesis and regulation of vascular tone, chemotaxis and lymphocyte trafficking, inflammation, and immunity (Anliker and Chun 2004; Hla 2004; Ishii et al. 2004; Meyer zu Heringdorf and Jakobs 2006). In addition, there is substantial functional evidence for intracellular actions of $\mathrm{S} 1 \mathrm{P}$, in particular, regulation of $\mathrm{Ca}^{2+}$ homoeostasis (reviewed in Young and Nahorski 2001; Meyer zu Heringdorf 2004).

Extra- and intracellular levels of S1P are tightly regulated by SphKs and S1P degrading enzymes. Diverse membrane receptors and signaling molecules stimulate SphK activity and expression, and the mechanisms by which SphK isoenzymes are specifically regulated are becoming increasingly clear, although there are still many open questions (Hait et al. 2006; Taha et al. 2006a), see below. Degradation of S1P occurs by dephosphorylation, catalyzed by S1P phosphatases (SPPs) and lipid phosphate phosphatases (LPPs), or by cleavage, catalyzed by S1P lyase (Brindley 2004; Saba and Hla 2004; Pyne et al. 2005). The non-specific LPPs dephosphorylate phosphatidic acid, LPA, ceramide-1-phosphate, and S1P, thereby generating diacylglycerol (DAG), monoacylglycerol, ceramide, and sphingosine, respectively (Brindley 2004; Pyne et al. 2005). LPPs are integral membrane proteins that are localized at the plasma membrane as well as intracellular membranes, their catalytic centers face the extracellular space and the luminal side of organelles, and they apparently can regulate extracellular as well as intracellular levels of lipid phosphates, including S1P (Brindley 2004; Pyne et al. 2005). The two known SPPs and S1P lyase are also integral membrane proteins and are localized at the endoplasmic reticulum. The catalytic center of SPPs has been predicted to face the luminal side, whereas that of S1P lyase is directed towards the cytosol (Brindley 2004; Ikeda et al. 2004). Both phosphatases and lyase regulate extraand intracellular levels of S1P and contribute to the cellular balance of relative levels of S1P, sphingosine, and ceramide (Mandala et al. 2000; Johnson et al. 2003; Reiss et al. 2004; Schwab et al. 2005).

Importantly, S1P, sphingosine, and ceramide can be interconverted by the sequential actions of SPPs and ceramide synthases, ceramidases, and SphKs, respectively (Fig. 1). Ceramide is furthermore formed by sphingomyelinases in response to many inducers of stress, such as heat, UV radiation, hypoxia/reperfusion, cytokines, or chemotherapeutic agents. Ceramide binds to several targets (Fig. 1) and appears to be involved in cellular stress responses, in particular, apoptosis (for review, see Hannun and Obeid 2002). Recently, the importance of ceramide-1phosphate and its formation by ceramide kinase has become more prominent, although still little is known about this mediator (Chalfant and Spiegel 2005). For more extensive review of sphingolipid metabolism, see Hannun et al. (2001), Hannun and Obeid (2002), Ogretmen and Hannun (2004), Futerman and Riezman (2005).

\section{Structural characteristics of SphKs}

Molecular identification of mammalian SphKs started with purification of rat kidney SphK to apparent homogeneity, which resulted in a protein of $49 \mathrm{kDa}$ (Olivera et al. 1998). Subsequently, mouse SphK1a and SphK1b variants, with 382 and 388 amino acids, respectively, were cloned and characterized (Kohama et al. 1998). The human SphK1 (Melendez et al. 2000; Nava et al. 2000; Pitson et al. 2000a) was found to have a high homology to the mouse enzyme (see Fig. 2). A second isoform of SphK was identified by blast searches of the expressed sequence tag database using the mouse SphK1 sequence (Liu et al. 2000a; Fig. 3). SphK2 is in large parts homologous to SphK1 but has 240 additional amino acids that are located at the $\mathrm{N}$ terminus and in the center of the enzyme, respectively (Liu et al. 2000a). SphKs are evolutionary highly conserved and have been identified for example in Saccharomyces cerevisiae, Dictyostelium discoideum, Caenorhabditis elegans, Drosophila melanogaster, and Arabidopsis thaliana (for review, see Taha et al. 2006a). Five conserved domains (C1C5) have been identified within SphKs, of which C1-C3 contain the DAG kinase catalytic domain, which is also found in DAG kinases and ceramide kinase, whereas C4 appears to be unique in SphKs (Kohama et al. 1998; Taha et al. 2006a).

SphK1 and SphK2 are differentially expressed in mammals. Northern blot analysis and quantitative PCR revealed that during embryonic development of the mouse, SphK1 expression was high at embryonic day 7 and decreased thereafter, whereas SphK2 expression increased gradually up to embryonic day 17 (Liu et al. 2000a; Kihara et al. 2006). In adult mouse tissues, SphK1 expression was highest in lung, spleen, kidney, and blood, whereas SphK2 was predominantly found in liver, kidney, brain, and heart (Liu et al. 2000a; Billich et al. 2003; Kihara et al. 2006). However, SphK activity can be measured in all mouse tissues (Fukuda et al. 2003; Billich et al. 2003).

Furthermore, the two mammalian SphK isoforms differ with respect to their substrate specificity and favored conditions. SphK1 clearly preferred D-erythro-sphingosine and D-erythro-dihydrosphingosine over other substrates, whereas SphK2 also phosphorylated phytosphingosine, 


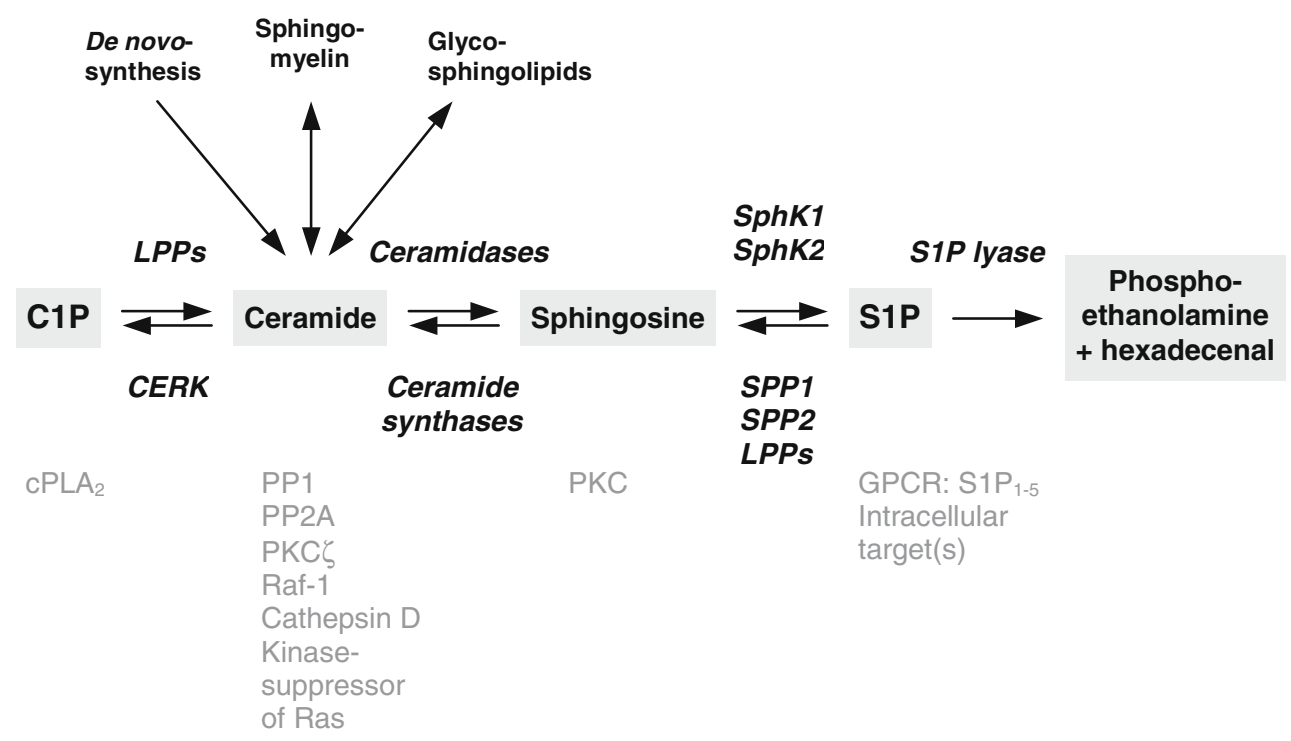

Fig. 1 Metabolic interconversion of C1P, ceramide, sphingosine, and S1P. Ceramide is in the center of sphingolipid metabolism, generated by de novo-sphingolipid synthesis or by sphingomyelin degradation. Ceramide is furthermore the starting point for synthesis of glycosphingolipids (Hannun et al. 2001; Ogretmen and Hannun 2004). Ceramide interacts with protein phosphatase- 1 and phosphatase-2A

DL-threo-dihydrosphingosine (threo-DHS) and, most importantly, FTY720 (Liu et al. 2000a; Billich et al. 2003). FTY720 (fingolimod) is a novel immunosuppressive that, after being phosphorylated by SphK, interacts with S1PGPCR, thereby interfering with lymphocyte trafficking (Brinkmann et al. 2004). Interestingly, FTY720 caused lymphopenia in mice lacking SphK1 but was inactive in mice lacking SphK2, which demonstrates the requirement of SphK2 for metabolic activation of this pro-drug (Allende et al. 2004; Kharel et al. 2005; Zemann et al. 2006). Ceramide, DAG, or phosphatidylinositol were not phosphorylated by SphKs. Threo-DHS and N,N-dimethylsphingosine (DMS) were competitive inhibitors of SphK1. In contrast, threo-DHS was phosphorylated by SphK2, albeit weakly, and DMS was a non-competitive inhibitor of SphK2 (Liu et al. 2000a). The $K_{\mathrm{m}}$ values of both SphK isoforms for D-erythro-sphingosine were in the range of 5$15 \mu \mathrm{M}$, the $\mathrm{K}_{\mathrm{m}}$ of SphK1 for ATP was 80-90 $\mu \mathrm{M}$ (Kohama et al. 1998; Liu et al. 2000a; Pitson et al. 2000a; Billich et al. 2003). Interestingly, the $V_{\max }$ of SphK1 was decreased by high salt concentrations $(>50 \mathrm{mM} \mathrm{NaCl}$ or $\mathrm{KCl}$ ), whereas that of SphK2 was enhanced under these conditions (Liu et al. 2000a). In contrast, Triton X-100 (0.05$0.5 \%$ ) enhanced SphK1 activity while suppressing SphK2 (Liu et al. 2000a). This differential activation of SphK1 and SphK2 by salt and detergents allows the separate measurement of the two kinases in cell and tissue lysates.

In the human genome, SPHK1 is localized to chromosome $17(17 \mathrm{q} 25.2)$ and SPHK2 to chromosome 19 (19q13.2). Of both $\mathrm{SphK}$ isoforms, several alternatively

(PP1, PP2A), PKC $\zeta$, Raf-1, cathepsin D, and the kinase suppressor of Ras (Snook et al. 2006). Sphingosine inhibits PKC. S1P activates specific GPCR as well as unknown intracellular target(s). C1P, formed from ceramide by ceramide kinase $(C E R K)$ was recently shown to directly activate cPLA 2 (Pettus et al. 2004). For further details, see text

spliced variants that differ at their $\mathrm{N}$ termini have been identified in man, mouse, and rat (Billich et al. 2003; Okada et al. 2005; Kihara et al. 2006). In the rat, six alternative first exons for SphK1 mRNA have been described, which were located within a $\mathrm{CpG}$ island serving as a template for the multiple SphK1 variants (Imamura et al. 2001). In man, at least three variants of SphK1 with 384, 399, and 470 amino acids [named SphK1a, SphK1b, and SphK1c (Venkataraman et al. 2006)] and two variants of SphK2 with 618 and 654 amino acids [named SphK-S and SphK-L or SphK2a and SphK2b (Okada et al. 2005; Venkataraman et al. 2006)], respectively, have been identified (see Figs. 2 and 3). Enzyme kinetics were found to be similar for the respective SphK1 and SphK2 variants (Billich et al. 2003). However, mouse SphK1 variants differed in stability and other aspects (Kihara et al. 2006). The murine SphK1b protein was unstable compared to SphK1a, displayed abnormal fast mobility in SDS gel electrophoresis, and formed homo-oligomers. Furthermore, mouse SphK1b was palmitoylated at its extra two Nterminal cysteine residues and localized to the plasma membrane where it was degraded by proteasome. In contrast, mouse SphK1a was a stable protein, localized mostly cytosolic and degraded only when membrane-bound (Kihara et al. 2006). In agreement, human SphK1b was located at the plasma membrane to a much greater extent than human SphK1a, whereas human SphK1c appeared to be associated with small membranous or vesicular compartments throughout the cytosol (Venkataraman et al. 2006). Of the two human SphK2 variants, SphK2-L/SphK2b was 
found to be the major form in several human cell lines and tissues (Okada et al. 2005). Whereas SphK2-S/SphK2a induced apoptosis through its putative BH3 domain (Liu et al. 2003) and inhibited DNA synthesis both in the absence and presence of serum (Okada et al. 2005), SphK2-L/ SphK2b decreased DNA synthesis only in the absence of serum, indicating a differential role of both isoforms (Okada et al. 2005). Furthermore, serum deprivation induced the expression of SphK2-L/SphK2b and its shuttling into the nucleus, and siRNA depletion of SphK2
Fig. 3 Amino acid sequences of various human $(h)$ and mouse $(m)$ SphK2 variants. The human SphK2 variants, represented by AF245447 and AL136701.1, correspond to SphK2-S and SphK2-L (Okada et al. 2005) or SphK2a and SphK2b (Venkataraman et al. 2006), respectively. Box Conserved diacyl glycerol kinase catalytic domain. Encircled 1 Glycine that is important for catalytic activity (corresponds to 1 in SphK1; Yoshimoto et al. 2003; Maceyka et al. 2005). Blue line Nucleotide-binding motif. Red line $\mathrm{Ca}^{2+} /$ Calmodulin binding site (Sutherland et al. 2006). Black line BH3 domain (Liu et al. 2003). Green line Nuclear localization signal (Igarashi et al. 2003)
Fig. 2 Amino acid sequences of various human $(h)$ and mouse (m) SphK1 variants.

NM_025367.4 corresponds to $\mathrm{mSphK} 1 \mathrm{a}_{2}$ (Kihara et al. 2006) and has one additional amino acid compared to the first described mSphK1a, whereas NM_011451.1 corresponds to mSphK1b (Kohama et al. 1998). The human SphK1 variants, represented by AF200328.1, NM 021972.2, and

NM_182965.1, have recently been named SphK1a, SphK1b, and $\mathrm{SphK} 1 \mathrm{c}$, respectively (Venkataraman et al. 2006). Box Conserved DAG kinase catalytic domain. Encircled 1 Glycine that is important for catalytic activity; mutation to aspartate leads to a dominant negative enzyme (Pitson et al. 2000b). Encircled 2 Aspartate that is required for sphingosine binding (Yokota et al. 2004). Encircled 3 Site for phosphorylation by ERK (Pitson et al. 2003). Encircled 4 Residues involved in phosphatidylserine binding (Stahelin et al. 2005). Blue line ATP binding site (Pitson et al. 2002). Red line $\mathrm{Ca}^{2+} /$ Calmodulin binding site (Sutherland et al. 2006). Black line TRAF2 binding site (Xia et al. 2002)
hSphK1 AF200328.1 hSphK1 NM_021972.2 hSphK1 NM 182965.1 mSphK1 NM_025367.4 mSphK1 NM_011451.1

hSphK1 AF200328.1 hSphK1 NM 021972.2 hSphK1 NM_182965.1 mSphK1 NM_025367.4 mSphK 1 NM 011451.1

hSphK1 AF200328.1 hSphK 1 NM_021972.2 hSphK I NM 182965.1 mSphK 1 NM 025367.4 mSphK1 NM_011451.1

hSphK1 AF200328.1 hSphK1 NM 021972.2 hSphK1 NM_182965.1 mSphK1 NM_025367.4 mSphK1 NM 011451.1

hSphK 1 AF200328.1 hSphK1 NM_021972.2 hSphK1 NM_182965.1 mSphK 1 NM 025367.4 mSphK1 NM_011451.1

hSphK1 AF200328.1 hSphK1 NM 021972.2 hSphK 1 NM 182965.1 mSphK1 NM_025367.4 mSphK1 NM 011451.1

hSphK1 AF200328.1 hSphK 1 NM 021972.2 hSphK1 NM_182965.1 mSphK1 NM 025367.4 mSphK1 NM_011451.1

hSphK1 AF200328.1 hSphK1 NM_021972.2 hSphK 1 NM 182965.1 mSphK 1 NM 025367.4 mSphK I NM 011451.1

hSphK1 AF200328.1 hSphK1 NM 021972.2 hSphK1 NM_182965.1 mSphK 1 NM 025367.4 mSphK1 NM 011451.1
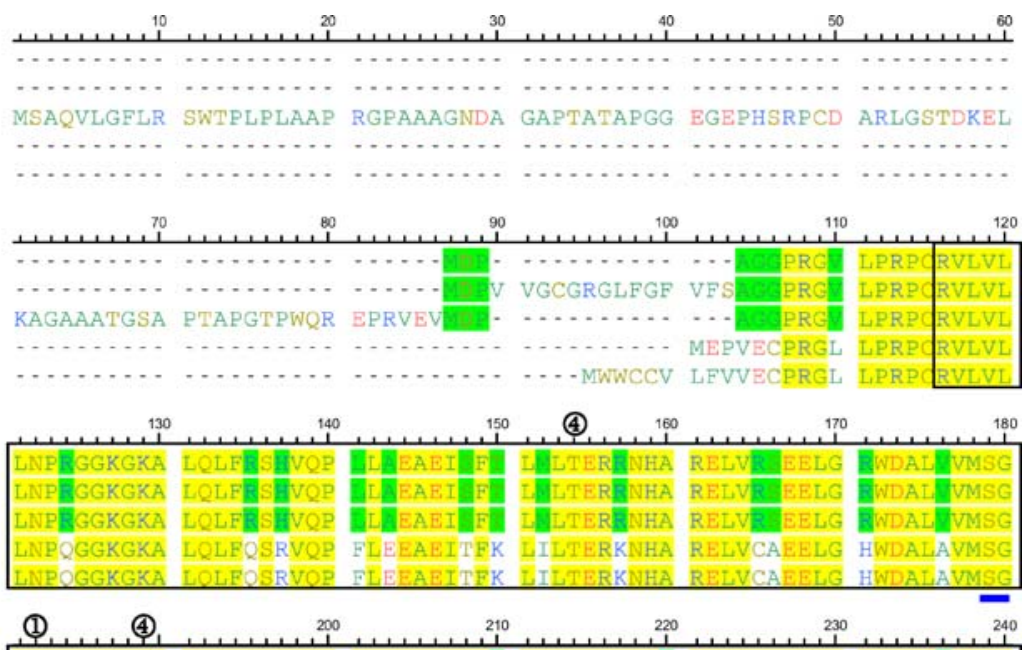
DGLMHEVVNG LMERPDWETA IOKPLCSLPA GSGNALAASI DGLMHEVVNG LMERPDWETA IOKPLCSLP GSGNALAAS NHYAGYEOVT NEDLI NCTL DGLMHEVVNG LMERPDWETA IQKPLCSLPA GSGNALAASE NHYAGYEQVT NEDLIINCTL GGMHEVVNG LMERPDWETA IQKPLCSLPG GSGNALAASV NHYAGYEQVT NEDLIINCTL DGLMHEVVNG LMERPDWETA IOKPLCSLPG GSGNALAASV NHYAGYEOVT NEDLLINCTL

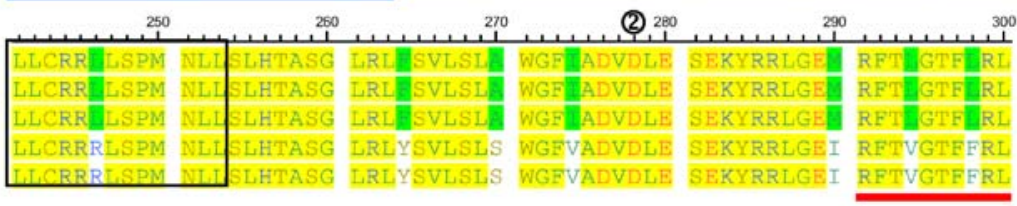

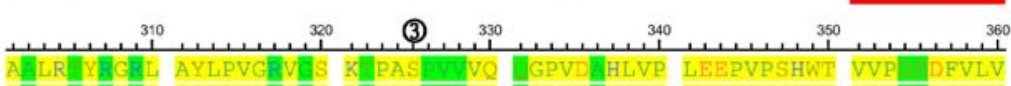

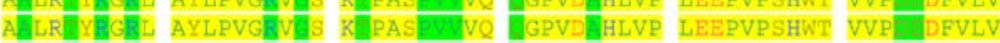

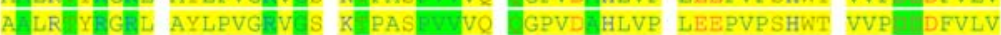
ASLRIYQGQL AYLPVGTVAS KRPAS-TLVQ KGPVDTHLVP LEEPVPSHWT VVPEQDFVLV ASLRIYQGQL AYLPVGTVAS KRPAS-TLVQ KGPVDTHLVP LEEPVPSHWT VVPEQDFVLV

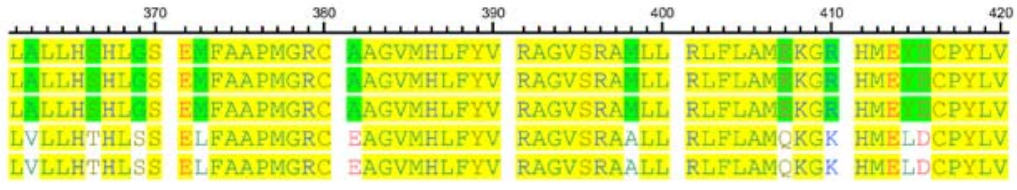

\begin{tabular}{|c|c|c|c|c|c|}
\hline 430 & 440 & 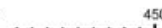 & 460 & 470 & 480 \\
\hline VPVVAFRLE & . & DGELMV IIUAV & NYFW & MV G & PPP \\
\hline VPVVAFRLE & $\mathrm{Pl}$ & DGELVVI & QGOVH & MVI & PPP \\
\hline VPVVAFRLE & PK GRG G F & MVË EAV & QGOVHPNY & MV G & PpP \\
\hline HVPVVAPRLE & PRSQRG FSV & DGELMVCEAV & QGQVHPNYLW & MVCGSRDAPS & RGPPP \\
\hline HVPVVAFRLE & PRSQRGV̄FSV & DGELMVCEAV & QGQVHPNYLW & MVCGSRDAPS & GRDSRRC \\
\hline
\end{tabular}

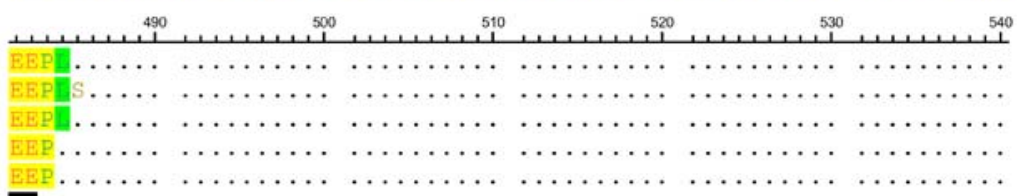


hSphK2 AF 245447 hSphK2 AL.136701.1 hSphK2 EF 107108 mSphK2 AK004951.1

hSphK2 AF245447

hSphK2 AL136701.1 hSphK2 EF 107108 mSphK2 AK004951.I

hSphK2 AF245447 hSphK2 AL136701.1 hSphK2 EF 107108 mSphK2 AK004951.

hSphK2 AF 245447 hSphK2 AL136701.1 hSphK2 EF 107108 mSphK2 AK004951.1

hSphK2 AF 245447 hSphK2 AL136701.1 hSphK2 EF 107108 mSphK2 AK004951.1

hSphK2 AF245447 hSphK2 AL136701.1 hSphK2 EF 107108 mSphK2 AK004951.1

hSphK2 AF245447 hSphK2 AL136701.1 hSphK2 EF 107108 mSphK2 AK004951. 1

hSphK2 AF 245447 hSphK2 AL 136701.1 hSphK2 EF 107108 mSphK2 AK004951.1

hSphK2 AF 245447 hSphK2 AL136701.1 hSphK2 EF 107108 mSphK2 AK004951.1

hSphK2 AF245447 hSphK2 AL136701.1 hSphK2 EF 107108 mSphK2 AK004951.1

hSphK2 AF245447 hSphK2 AL136701.1 hSphK2 EF 107108 mSphK2 AK004951.1

hSphK2 AF245447 hSphK2 AL136701.1 hSphK2 EF 107108 mSphK2 AK004951.1

hSphK2 EF 107108

\begin{tabular}{|c|c|c|c|c|c|}
\hline$\underset{1.1}{\cdots}$ & - & : & $\stackrel{40}{.}$ & . & 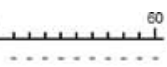 \\
\hline & $\ldots \ldots$ & … & .... & $\ldots$ & . \\
\hline VS & GPLWDAGLCP & ASSRSAHTCL & SLSVSDAPVS & PATAFHCLLL & STAPAPPCPC \\
\hline & & & & & \\
\hline & & & & & \\
\hline & & & & ST & \\
\hline & & & & ST & SSY \\
\hline VLNSHPFS & PPFPQRPDQE & LTGSWGHGPR & STLVRAKA晋 & PPEDPAAST & FGSY \\
\hline ... & & 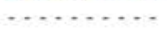 & $\cdots M-M A P$ & PPLLPVAAST & ILHGEFGSY \\
\hline
\end{tabular}



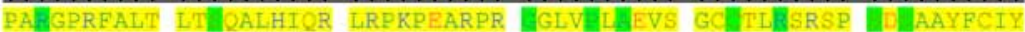

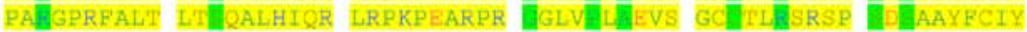

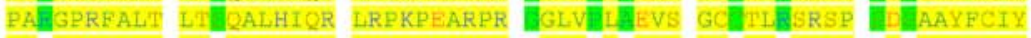
PANGPRFALT LTTQALHIQR LRPKPEARPR DGLVSLDEVS GCGTLQSRSP EDTAAYFCIY

\begin{tabular}{|c|c|c|c|c|c|}
\hline 190 & ${ }^{200}$ & 210 & 220 & 230 & \\
\hline G] $R$ & RRATRTFRAD & GA & EAQRWATALT & CLILRG & DEETARILI \\
\hline G曾R & RRATRTFRAD & GA & ALT & GIIIIG & 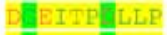 \\
\hline E & RAD & NRA & ALT & PI Big & 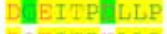 \\
\hline & $\angle A D$ & NRA & ALT & LSG & DQE \\
\hline & ${ }^{250}$ & 270 & & & \\
\hline $\mathbb{N}$ & PEGG & MI & NLI & RE & LV \\
\hline & PEG & IPMI & NLI & & I \\
\hline DLVN & WQ & HVIPMI & NLI & & \\
\hline & & & & & \\
\hline
\end{tabular}

$\begin{array}{llllll}\text { (1) } 300 & 330 & 340 & 350 & 360\end{array}$

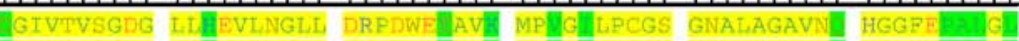

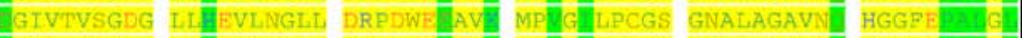

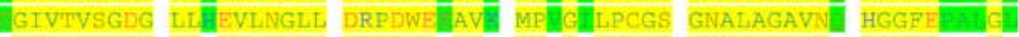
EGTVUVSGDG WYYVINGLS DRPDWEDAVR MPTGVLPCGS GNALAGAVNH HGGPEOVVGV

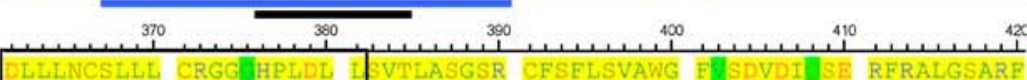
DLLLNCSLIL CRGG HPLDL I VILASGSR CFSELSVAWG FIISDVDIIISE RFRALGSARP DLLLNCSLLL CRGGHPLDL IVTLASGSR CFSFLSVAWG FIISDVDI ISE RFRALGSARF DLLLNCSLLI CRGGSHPLDL I VTLASGSR CFSFLSVAWG FLSDVDIHSE RFRALGSARE

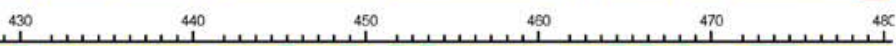

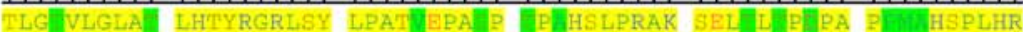

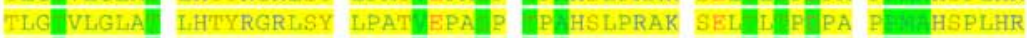

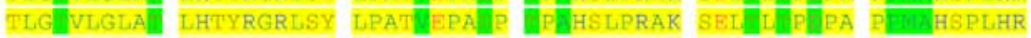
TLGAVLGLAS LHTYRGRLSY LPATTEPALP IPGHSLPRAK SELVLAPAPA PAATHSPLHR

\begin{tabular}{|c|c|c|c|c|c|}
\hline 490 & 500 & 510 & 520 & 530 & \\
\hline $\mathrm{LP}$ & QPAL/ISPGSP & EPL: & GGPEI IIGDWG & SPD & PI \\
\hline LP & QPAL & EPLPIILSLNG & GGPELIEDWW & USPD & $\mathrm{P}$ \\
\hline VSDLPLPLP & ISPGSP & ILSLNG & LIGDWG & $\angle S P D$ & D \\
\hline SDLPI & & EPL: & GGPEL & GAGDAPLSPD & PL: \\
\hline
\end{tabular}

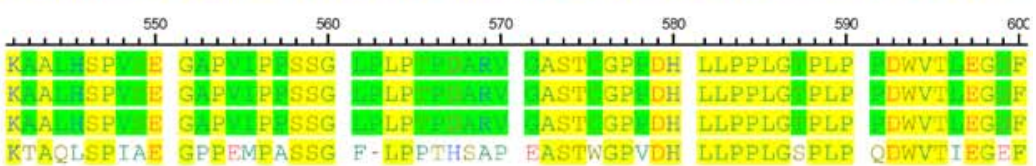

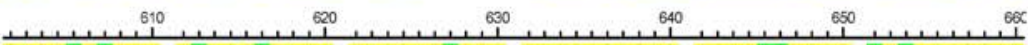

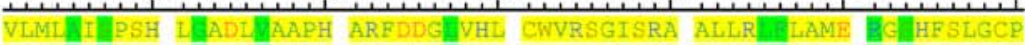
VLMI MIIPSH LIADI AAPH ARFDDGIVHL CWVRSGISRA ALLR IAAME RG HESLGCP

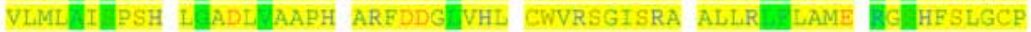
VLMLGILPSH LCADLMAAPH ARFDDGVVHL CWVRSGISRA ALLRILLAME HGNHFSLGCP

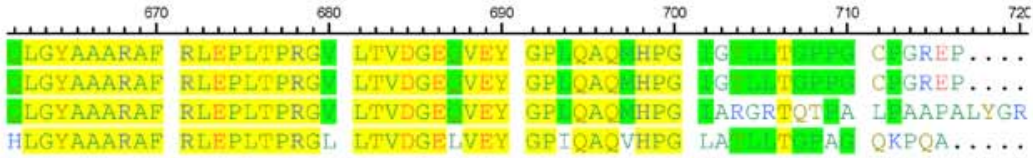

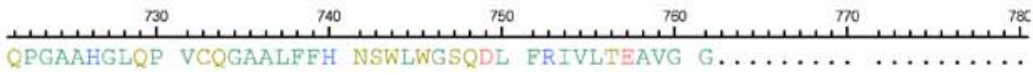


protected the cells from serum deprivation-and druginduced apoptosis (Okada et al. 2005). Together with a previous report describing $\mathrm{SphK} 2-\mathrm{S} / \mathrm{SphK} 2 \mathrm{a}$ as pro-apoptotic BH3 only-protein (Liu et al. 2003), these data indicate that SphK2 is involved in the regulation of apoptosis (Okada et al. 2005; see below). We have identified another variant of human SphK2 (gene bank accession number EF107108) that contains 761 amino acids and differs from the previously described SphK2 variants by a prolonged $\mathrm{N}$-terminal extension and a modified $\mathrm{C}$ terminus (SphK2c, Fig. 3). Compared to SphK2-S/SphK2a, which is organized in five exons on chromosome 19, SphK2-L/SphK2b comprises two additional exons in $5^{\prime}$ direction, whereas SphK2c has a $5^{\prime}$-extension of exon 1 and a sixth exon encoding the $\mathrm{C}$ terminus (Fig. 4). Expression of the full-length SphK2c mRNA in HEK-293 and HL-60 cells was confirmed by PCR (data not shown). However, we were not able to express the full-length protein so far.

SphKs have a DAG kinase catalytic domain (see Figs. 2 and 3), which contains the nucleotide binding site (consensus sequence SGDGX $_{17-21} \mathrm{~K}$; Pitson et al. 2002). By comparison with DAG kinases, a glycine residue (glycine82 in human SphK1a, position 182 in Fig. 2) was identified in SphK1 as essential for catalytic activity. Mutation to aspartate (G82D mutation) resulted in a catalytic inactive enzyme that acted in a dominant negative manner and has been widely used to dissect SphK signaling pathways (Pitson et al. 2000b). The corresponding glycine in SphK2 (glycine-212 in SphK2-S/SphK2a, position 310 in Fig. 3) was similarly required for enzymatic activity (Yoshimoto et al. 2003; Maceyka et al. 2005). Another glycine (glycine133 of human SphK1a, position 213 in Fig. 2) furthermore regulated SphK1 catalytic activity; mutation to aspartate decreased, whereas mutation to alanine enhanced activity (Pitson et al. 2001). Sphingosine binding was assigned to the C4 domain (Yokota et al. 2004). In mouse SphK1a, aspartate-177 (position 278 in Fig. 2) was particularly

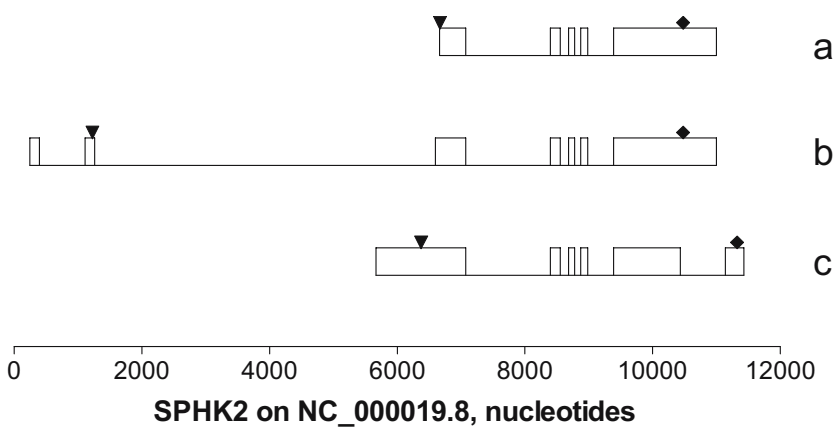

Fig. 4 Genomic organization of SphK2 variants. Exons are represented by boxes, introns by lines. Nucleotide sequences of variants $a$, $b$, and $c$ have been derived from gene bank accession numbers AF245447, AL136701.1, and EF107108, respectively. For corresponding amino acid sequences, see Fig. 3. Inverted triangle, start; diamond, stop of translation important, as its mutation to asparagine enhanced the $K_{\mathrm{m}}$ for sphingosine, but not ATP, and dramatically decreased enzyme activity (Yokota et al. 2004).

\section{Regulation of SphKs}

SphK activity in general is stimulated for example by GPCR agonists (muscarinic receptor agonists, formyl peptide, nucleotides, LPA and S1P, bradykinin), agonists at receptor tyrosine kinases [PDGF, epidermal growth factor (EGF), nerve growth factor (NGF), vascular endothelial growth factor (VEGF)], cross-linking of immunoglobulin receptors, tumor necrosis factor- $\alpha$ (TNF- $\alpha)$, transforming growth factor- $\beta$ (TGF- $\beta$ ), interleukins (ILs), $\mathrm{Ca}^{2+}$ increasing agents, and phorbol ester (reviewed in Maceyka et al. 2002; Meyer zu Heringdorf 2004; Taha et al. 2006a). Whereas many stimuli cause a rapid, transient stimulation of SphK activity, most likely by posttranslational modification or by affecting its localization, other agents induce a biphasic course of SphK activation, with a first rapid increase in enzymatic activity that is followed by a prolonged transcriptional upregulation. Upregulation of SphK1 expression was induced for example by estrogen (Sukocheva et al. 2003), 1,25dihydroxyvitamin D3 (Manggau et al. 2001), EGF (Döll et al. 2005), and histamine (Huwiler et al. 2006).

The pathways and molecular mechanisms by which SphK isoforms are acutely activated in a specific manner are not entirely clear. SphK1 appears to be regulated by protein-protein interactions, phosphorylation, phosphatidic acid, $\mathrm{Ca}^{2+}$, and subcellular localization.

Regulation of SphK1 by TNF- $\alpha$, phosphorylation, and phosphatidylserine binding Activation of SphK1 by TNF$\alpha$, an important pro-inflammatory cytokine, required its binding to TNF receptor-associated factor-2 (TRAF2; Xia et al. 2002). Deletion of the TRAF2 binding consensus site, PPEE (Fig. 2), abrogated the interaction of SphK1 with TRAF2 and the stimulation of SphK1 by TNF- $\alpha$ but not by phorbol ester (Xia et al. 2002). Phorbol ester, via protein kinase C, stimulated phosphorylation of SphK1 and its translocation to the plasma membrane (Johnson et al. 2002). Both TNF- $\alpha$ and phorbol ester stimulated phosphorylation of SphK1 by extracellular signal-regulated kinase (ERK1/2) at serine-225 (position 325 in Fig. 2), and this phosphorylation was required for agonist stimulation of SphK activity and translocation of SphK1 to the plasma membrane (Pitson et al. 2003). On the other hand, SphK1 was also required for TNF- $\alpha$-stimulated ERK activation (Pitson et al. 2000b), indicating some complexity of ERK/ SphK1 interaction. Interestingly, in vitro phosphorylation of SphK1 greatly enhanced its activity (Pitson et al. 2003), but the basal cellular S1P production by the non-phosphorylat- 
able SphK1-S225A mutant was not much lower than that caused by the wild-type enzyme (Pitson et al. 2005). Whereas overexpression of wild-type SphK1 enhanced growth of NIH3T3 cells, expression of the SphK1-S225A mutant stimulated growth and colony formation only when it was artificially targeted to the plasma membrane. These data suggest that the localized production of S1P at the plasma membrane, rather than the overall enhancement of SphK activity, mediated the oncogenic effect (Pitson et al. 2005). The data furthermore suggest that phosphorylation at serine-225 does not primarily stimulate SphK1 activity (as suggested in Pitson et al. 2003), but rather the SphK1 membrane translocation (as shown in Pitson et al. 2005). Other authors reported that plasma membrane-targeted SphK1 reduced the growth of 3 T3 L1 fibroblasts by delaying exit from $G_{0} / G_{1}$ phase and protected the cells from apoptosis induced by serum withdrawal (SafadiChamberlain et al. 2005). Plasma-membrane-localized SphK1 can cause S1P release into the medium, leading to activation of S1P-GPCR. The cellular effects caused by this process are cell-type specific depending on the expressed S1P-GPCRs and their respectively signaling (see "Insideout and intracellular signaling by SphKs"). Recently, a mechanism for membrane targeting of SphK1 has been suggested, which involves phosphatidylserine binding (Stahelin et al. 2005). SphK activity was enhanced by acidic phospholipids, particularly phosphatidylserine, and SphK1 selectively bound to this lipid in vitro (Olivera et al. 1996; Stahelin et al. 2005). The conserved threonine-54 and asparagine-89 (positions 154 and 189 in Fig. 2) were essential for phosphatidylserine binding as well as plasma membrane translocation and S1P secretion in intact cells (Stahelin et al. 2005). Mutation of serine-225 to alanine did not prevent, as reported by Pitson et al. (Pitson et al. 2003), but reduced plasma membrane translocation of SphK1 and affected phosphatidylserine binding. A model was suggested in which phosphorylation of serine-225 caused exposure of threonine-54 and asparagine- 89 and/or other phosphatidylserine-binding residues, thereby facilitating membrane association (Stahelin et al. 2005). Enzymatic activity would be enhanced in this model by bringing SphK1 in close contact to its substrate, sphingosine, and by the stimulatory action of phosphatidylserine.

Regulation of SphK1 by phospholipase D Using antisense nucleotides against phospholipase D (PLD) 1, it was demonstrated that SphK1 was activated via PLD1 in human mast cells (Melendez and Khaw 2002). In agreement, recombinant purified SphK1 bound to phosphatidic acid, the interaction site being located within the C-terminal half of the enzyme (Delon et al. 2004). SphK1 furthermore colocalized with PLD1 at endosomal compartments, although no evidence for a direct interaction of both enzymes was obtained, indicating that SphK1 interacted with phosphatidic acid but not with PLD1 (Delon et al. 2004). Interestingly, in a mixture of separately obtained cytosol and membranes, SphK1 translocated from the cytosol to the membranes upon addition of PLD from Streptomyces chromofuscus in the presence of $\mathrm{Ca}^{2+}\left(\mathrm{Ca}^{2+}\right.$ was required for activation of the bacterial enzyme; Delon et al. 2004). ATP, which alone induced translocation of a small proportion of SphK1, furthermore enhanced the PLD effect, suggesting that phosphorylation might play an additional role (Delon et al. 2004).

Regulation of SphK activity by $\mathrm{Ca}^{2+}$ Several data suggest that $\mathrm{SphKs}$ are involved in receptor-induced $\mathrm{Ca}^{2+}$ mobilization from intracellular stores (see below and Meyer zu Heringdorf 2004). However, some reports suggest that SphKs, in particular SphK1, also require $\mathrm{Ca}^{2+}$ for catalytic activity. Chelation of intracellular $\mathrm{Ca}^{2+}$ inhibited formyl peptide-, nucleotide-, and $\mathrm{M}_{3}$ receptor-stimulated $\mathrm{S} 1 \mathrm{P}$ production in HL-60 granulocytes and HEK-293 cells, respectively, whereas $\mathrm{Ca}^{2+}$ increasing agents enhanced basal S1P formation (Alemany et al. 2000). On the other hand, SphK activity was required in these cells for $\mathrm{Ca}^{2+}$ mobilization by the above-mentioned receptors (Meyer $\mathrm{zu}$ Heringdorf et al. 1998; Alemany et al. 1999). In PC12 cells, $\mathrm{Ca}^{2+}$ influx via voltage-gated $\mathrm{Ca}^{2+}$ channels elevated S1P levels, whereas overexpression of SphK1 clearly enhanced noradrenaline release, suggesting that SphK1 sensed and augmented the $\mathrm{Ca}^{2+}$ increase (Alemany et al. 2001). SphK1 binds to $\mathrm{Ca}^{2+}$ /calmodulin (Kohama et al. 1998); however, a direct activation of the enzyme by $\mathrm{Ca}^{2+}$ has not been demonstrated so far. It has been suggested that $\mathrm{Ca}^{2+} /$ calmodulin did not stimulate the activity but the translocation of SphK1 to the plasma membrane, as $\mathrm{M}_{3}$ receptor-stimulated SphK1 translocation was inhibited by a calmodulin inhibitor in SH-SY5Y cells (Young et al. 2003). Several putative calmodulin-binding sites have been suggested by sequence analysis of SphK1 (Kohama et al. 1998; Taha et al. 2006a). Recently, however, the calmodulin-binding site was ascribed to residues 191-206 of human SphK1a (positions 292-306 in Fig. 2). Without a functional calmodulin-binding site, SphK1 did not translocate to the plasma membrane upon stimulation with phorbol ester, but its catalytic activity and phosphorylation remained intact (Sutherland et al. 2006).

Other mechanisms of SphK1 regulation Several proteins have been identified that directly interact with SphK1, for example, a protein kinase A anchoring protein-related protein (also named SphK-interacting protein), aminoacylase-1, platelet endothelial cell adhesion molecule-1, RPK118, and others (reviewed in Taha et al. 2006a). The functional significance of these interactions is not fully clear at present. Hepatocyte growth factor required the 
tyrosine phosphatase, Shp-2, for activation of SphK1 in embryonic fibroblasts, and Shp-2 was co-immunoprecipitated with SphK1, indicating a direct interaction (Duan et al. 2006). Recently, a negative regulation of SphK1 by TNF- $\alpha$ has been described (Taha et al. 2005). Prolonged treatment of MCF-7 cells with TNF- $\alpha$ initiated apoptosis, which involved the disruption of lysosomes and release of cathepsin B to the cytosol, and this cysteine protease cleaved SphK1 at multiple sites, thereby downregulating the pro-survival enzyme during the apoptotic process (Taha et al. 2005, 2006b).

Regulation of SphK1 and SphK2 by directed localization Looking at the mechanisms by which SphKs can be activated, it comes to attention that SphK1 has a substantial basal activity, and stimulation with agonists often leads to only $\sim 1.5$ - to 2 -fold increase in catalytic activity. Therefore, SphK1 signaling might rather be regulated by translocation to subcellular compartments than by a major increase in its catalytic activity (discussed in Wattenberg et al. 2006). Under resting conditions, SphK1 is a cytosolic enzyme that is translocated to the plasma membrane, as described above, by several stimuli. However, SphK1 also translocated to perinuclear, probably endosomal, compartments upon induction of PLD1 (Delon et al. 2004). In human macrophages, SphK1 was recruited to nascent phagosomes, and this process was independent of its catalytic activity or phosphorylation at serine-225 but dependent on $\mathrm{Ca}^{2+}$ (Thompson et al. 2005). Interestingly, both SphK1 translocation to phagosomes and macrophage SphK activity were inhibited by Mycobacterium tuberculosis, which inhibits phagosome maturation and is able to survive within macrophages. SphK inhibition by threo-DHS also blocked phagosome maturation, suggesting that the effect of $M$. tuberculosis on SphK contributed to survival of the pathogen within macrophages (Malik et al. 2003; Thompson et al. 2005). Two nuclear export sequences were identified in SphK1, and deletion of these sequences or inhibition of nuclear export caused nuclear accumulation of the enzyme, indicating that SphK1 can shuttle between cytosol and nucleus (Inagaki et al. 2003). SphK2, on the other hand, has been identified predominantly in the cytosol and nucleus. In HeLa and COS-7, but not HEK-293 cells, SphK2 was localized predominantly in the nucleus, and a nuclear localization signal was mapped to the N-terminal part of SphK2 (see Fig. 3; Igarashi et al. 2003). Studies with SphK1 and $\mathrm{SphK} 2$ variants suggest that the $\mathrm{N}$ terminus has a major impact on subcellular localization (Venkataraman et al. 2006). Furthermore, serum depletion promoted the association of SphK2 with the endoplasmic reticulum (Maceyka et al. 2005). Taken together, these data are in agreement with an extra- as well as intracellular signaling role of S1P.
Regulation of SphK2 First reports suggest that SphK2 can also be regulated by agonists. EGF stimulated SphK2 in HEK-293 and MDA-MB-453 breast cancer cells (Hait et al. 2005). Downregulation of SphK2 completely eliminated migration towards EGF in the breast cancer cells, whereas it had no effect in HEK-293 cells, indicating cell type-specific signaling by SphK2. SphK2 furthermore interacted directly with the cytoplasmic region of the IL-12 receptor subunit, IL-12R $\beta 1$, and expression of dominant negative SphK2 suppressed IL-12-stimulated production of interferon- $\gamma$ (Yoshimoto et al. 2003). In mast cells, it was recently shown that the immunoglobulin E receptor, FceRI, not only activated SphK1, as reported before, but also SphK2 (Olivera et al. 2006). The Src tyrosine kinase, Fyn, was required for stimulation of SphK1 and SphK2 by FceRI and for basal activity of SphK2. Furthermore, Fyn was required for IL-3-induced activation of SphK1 but not SphK2. Finally, both SphK1 and SphK2 directly interacted with the Fyn kinase (Olivera et al. 2006). Altogether, the regulation of SphK2 appears to be complex and requires further investigation.

\section{Inside-out and intracellular signaling by SphKs}

Cellular S1P, produced by SphKs, can be exported and act on S1P-GPCR, a process which is called inside-out signaling (Spiegel and Milstien 2003). On the other hand, substantial evidence supports an additional intracellular role of S1P (discussed in Meyer zu Heringdorf 2004; Chalfant and Spiegel 2005). Overexpression of SphK1 induced stress fiber formation via $\mathrm{G}_{12 / 13}$-proteins in NIH3T3 cells, indicating the involvement of S1P-GPCR. In contrast, SphK1 overexpression stimulated proliferation and protected from apoptosis even in fibroblasts derived from $\mathrm{S}_{1} \mathrm{P}_{2 / 3}$ double knockout mice, in which neither $\mathrm{S}_{1} \mathrm{P}_{4}$ nor

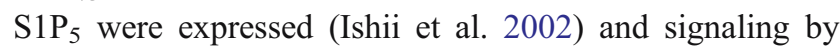

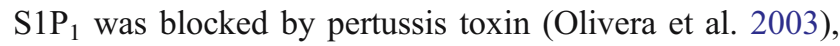
suggesting that intracellular S1P mediated proliferation and survival in mouse embryonic fibroblasts. In contrast, NGF, via its TrkA receptor, stimulated plasma membrane translocation of SphK1 and activated the $\mathrm{S}_{1} \mathrm{P}_{1}$ and $\mathrm{S}_{1} \mathrm{P}_{2}$ receptors in a SphK1-dependent manner in $\mathrm{PC} 12$ and dorsal root ganglion cells, and NGF-induced neurite extension was suppressed by downregulation of $\mathrm{S}_{1} \mathrm{P}_{1}$ (Toman et al. 2004). Cross-linking of FceRI in mast cells not only activated SphK but also stimulated S1P secretion and activation of $\mathrm{S}_{1} \mathrm{P}_{1}$ and $\mathrm{S}_{1} \mathrm{P}_{2}$, which were internalized upon FcERI activation. $\mathrm{S}_{1} \mathrm{P}_{1}$ was required for migration of mast cells towards antigen, whereas $\mathrm{S}_{1} \mathrm{P}_{2}$ was required for degranulation (Jolly et al. 2004). These data, however, are in contrast to the hypothesis of Melendez et al., who 
suggested that $\mathrm{Ca}^{2+}$ release by intracellular $\mathrm{S} 1 \mathrm{P}$ was involved in SphK1-dependent mast cell degranulation (Melendez and Khaw 2002), and to the report by Spiegel et al., demonstrating that S1P export via an ATP binding cassette $(\mathrm{ABC})$ transporter was involved in migration but not degranulation of mast cells (Mitra et al. 2006). S1P signaling inside-out via the $\mathrm{S}_{1} \mathrm{P}_{1}$ receptor furthermore contributed to PDGF-stimulated cell migration (Hobson et al. 2001), although the mutual cross-activation of the $\mathrm{S}_{1} \mathrm{P}_{1}$ and PDGF receptors might also be based on a receptor signaling platform (Waters et al. 2006). Recently, it was shown that insulin-like growth factor (IGF) promoted the translocation of SphK1 to the plasma membrane, increased SphK activity, and induced internalization of the $\mathrm{S}_{1} \mathrm{P}_{1}$ receptor (El Shewy et al. 2006). IGF-stimulated ERK activation was inhibited by SphK1 silencing and the $\mathrm{S}_{1 / 3}$ antagonist, VPC23019, indicating that both SphK1 and $\mathrm{S}_{1} \mathrm{P}_{1}$ were required for ERK activation by IGF (El Shewy et al. 2006).

Not only S1P but also SphK1 can apparently be released from cells (Ancellin et al. 2002; Venkataraman et al. 2006). SphK1 was constitutively excreted by vascular endothelial cells and HEK-293 cells by a nonclassical secretory pathway (Ancellin et al. 2002). Of SphK1 and SphK2 variants transfected in HEK-293 cells, $\sim 3.5 \%$ of SphK1a but less than $1 \%$ of SphK1b and SphK1c were secreted, whereas SphK2 was not secreted by vascular endothelial or HEK-293 cells (Venkataraman et al. 2006). As haematopoietic cells including platelets express SphKs, it was not surprising that mouse and human blood contained substantial SphK activity. Plasma S1P levels in SphK1 null mice were less than half of control mice, indicating that SphK1 contributed to the S1P gradient between plasma and tissues (Venkataraman et al. 2006). Although SphK activity in mouse platelet-poor plasma was comparably low, it was suggested that plasma contained soluble SphK1 (Venkataraman et al. 2006). Human plasma contained even lower SphK activity, but this activity could be attributed to SphK1 by immunoprecipitation (Venkataraman et al. 2006).

Recent interest has focused on the mechanisms by which S1P can be extruded from cells. By studying platelets, Kobayashi et al. came to the conclusion that two independent S1P releasing systems might exist in the platelet plasma membrane, an ATP-dependent system stimulated by thrombin, and an ATP-independent system stimulated by $\mathrm{Ca}^{2+}$ (Kobayashi et al. 2006). ATP- and thrombin-stimulated $\mathrm{S} 1 \mathrm{P}$ release were inhibited by the $\mathrm{ABC}$ transporter inhibitor, glyburide, whereas $\mathrm{Ca}^{2+}$-stimulated release was not (Kobayashi et al. 2006). Very recently, the involvement of the $\mathrm{ABC}$ transporter, $\mathrm{ABCC} 1$, in cellular $\mathrm{S} 1 \mathrm{P}$ release was demonstrated in mast cells using specific inhibitors and siRNA (Mitra et al. 2006). S1P export by ABCC1 was required for migration but not degranulation of mast cells (Mitra et al. 2006).

Despite the many examples for inside-out signaling by SphKs and S1P, there is compelling evidence for an additional intracellular role of S1P (discussed, e.g., in Spiegel and Milstien 2003; Meyer zu Heringdorf 2004; Chalfant and Spiegel 2005). There are three major lines of evidence for intracellular signaling by S1P. First of all, signaling by SphKs and S1P has been demonstrated in organisms such as yeast, Dictyostelium, plant, flies, and worms, whereas S1P-GPCR apparently developed later in evolution, suggesting that other S1P targets must exist (Saba and Hla 2004). Second, the intracellular localization of SphKs, in particular, the localization of SphK2 in the nucleus, the translocation of SphK1 to intracellular sites by PLD1 and during phagocytosis, and the localization of S1P lyase and SPPs at the endoplasmic reticulum, suggest a localized, intracellular S1P signaling (see above). This is supported by the fact that for inside-out signaling, SphK1 is shuttled to the plasma membrane. Third, several studies described intracellular S1P actions that were not imitated by extracellular S1P and could not be attributed to S1P-GPCR signaling (reviewed in Meyer zu Heringdorf 2004; Chalfant and Spiegel 2005). Intracellular S1P, released from caged S1P by photolysis, mobilized $\mathrm{Ca}^{2+}$ from thapsigarginsensitive stores even in cells that did not express the known S1P-GPCR and in which extracellular S1P was inactive (Meyer zu Heringdorf et al. 2003). A role for SphK in the regulation of $\mathrm{Ca}^{2+}$ was furthermore shown recently in NIH3T3 cells, in which SphK2 translocated to the endoplasmic reticulum under serum starvation, and basal cytosolic $\mathrm{Ca}^{2+}$ levels were elevated under serum-free conditions in SphK2-overexpressing cells (Maceyka et al. 2005). A role for SphK in agonist- and receptor-stimulated $\mathrm{Ca}^{2+}$ mobilization has been shown predominantly by using not only the non-specific SphK inhibitors, threo-DHS and DMS (many publications; for review, see Meyer zu Heringdorf 2004), but also by SphK1 antisense (Melendez and Khaw 2002; Melendez and Ibrahim 2004). SphK1 antisense abrogated the fast increase in intracellular $\mathrm{Ca}^{2+}$ $\left(\left[\mathrm{Ca}^{2+}\right]_{\mathrm{i}}\right)$, which was required for degranulation in mast cells (Melendez and Khaw 2002). However, inside-out signaling via $\mathrm{S}_{1} \mathrm{P}_{2}$ was later shown to drive degranulation of mast cells in response to FceRI-mediated SphK1 activation (Jolly et al. 2004), although this has been questioned (Mitra et al. 2006; see above). SphK1 antisense, furthermore, nearly abrogated $\left[\mathrm{Ca}^{2+}\right]_{\mathrm{i}}$ increases by the complement component, $\mathrm{C} 5 \mathrm{a}$, in macrophages and strongly inhibited degranulation, cytokine release, and migration of these cells in response to C5a (Melendez and Ibrahim 2004). Interestingly, SphK1-deficient mice had normal inflammatory responses (e.g., thioglycollate-induced peritonitis and collagen-induced arthritis; Michaud et al. 2006). 
Furthermore, formyl peptide was fully able to stimulate NADPH oxidase activity and activation of several kinases, among them ERK and p38, in SphK1 null neutrophils (Michaud et al. 2006). The latter is in agreement with previous studies in HL-60 cells, which demonstrated that specifically $\left[\mathrm{Ca}^{2+}\right]_{\mathrm{i}}$ increases and degranulation were dependent on SphK, but neither formyl peptide-stimulated superoxide production nor nucleotide-stimulated ERK, JNK, or p38 activation were affected by SphK inhibitors in these cells (Alemany et al. 1999, 2000). Nevertheless, an important role for SphK1 in inflammation could not be confirmed by studies in SphK1 null mice so far, although neither SphK2 was upregulated nor S1P degrading enzymes were downregulated for compensation (Michaud et al. 2006). This is in clear contrast to studies in mast cells and macrophages in which SphK1 was reduced by antisense or siRNA (Olivera and Rivera 2005; Kee et al. 2005) and might be due to unknown adaptation processes.

\section{Physiological and pathophysiological roles of SphKs}

SphKs have been implicated in proliferation, survival, migration and regulation of $\mathrm{Ca}^{2+}$ homoeostasis, development and regulation of the cardiovascular and nervous systems, inflammation, immunity, and cancer growth (Hait et al. 2006; Taha et al. 2006a). S1P appears to be produced in vivo by SphKs; other pathways, for example cleavage of sphingosylphosphorylcholine by autotaxin (Clair et al. 2003), have not been proven to occur within a living organism. Therefore, all actions of S1P might be directly or indirectly dependent on SphKs. In agreement, mouse embryos deficient in both SphK1 and SphK2 had no measurable S1P levels (Mizugishi et al. 2005). Interestingly, SphK activity was substantially decreased in $\mathrm{SphK} 1^{--}$ mice, whereas S1P tissue levels were essentially normal (Allende et al. 2004), indicating that SphK1 deficiency could be compensated for. Merely in serum, S1P levels were reduced by $\sim 50 \%$ in SphK1 $1^{-/-}$mice (Allende et al. 2004; Zemann et al. 2006). In comparison, in SphK2 $2^{-/}$ mice, plasma S1P levels were reduced by only $\sim 25 \%$, whereas serum levels were not reduced, indicating that both kinases, with predominance of SphK1, contributed to plasma and serum S1P (Kharel et al. 2005; Zemann et al. 2006). However, it has to be considered that S1P levels are as well regulated by the degrading enzymes, S1P lyase and diverse phosphatases. The S1P lyase inhibitor, 2-acetyl-4tetrahydroxybutylimidazole, greatly enhanced S1P levels in thymus, spleen, and lymph nodes (Schwab et al. 2005), and depletion of SPP1 by siRNA elevated S1P levels in cell culture supernatants (Johnson et al. 2003), indicating the importance of these enzymes in maintaining S1P homeostasis.
Genetic deletion of either SphK1 or SphK2 in the mouse caused no greater abnormalities (Allende et al. 2004; Michaud et al. 2006; Kharel et al. 2005; Zemann et al. 2006). Furthermore, SphK1-deficient mice had normal acute and chronic inflammatory responses (Michaud et al. 2006), see above. In contrast, deletion of both SphK1 and SphK2 led to embryonic lethality before day 13.5 because of severe bleeding (Mizugishi et al. 2005). The wall of dorsal aorta was poorly developed, and the covering by vascular smooth muscle cells was incomplete, suggesting a migratory defect in smooth muscle cell precursors, as also observed in mice deficient in the $\mathrm{S}_{1} \mathrm{P}_{1}$ receptor (Mizugishi et al. 2005; Liu et al. 2000b; Allende and Proia 2002). $\mathrm{SphK}^{-/-} \mathrm{SphK}^{-/-}$mice furthermore had a cranial neural tube defect, which occurred in $20 \%$ at embryonic day 12.5 , indicating the importance of S1P for the development of the central nervous system (Mizugishi et al. 2005). In agreement, SphK1 was found to be expressed in the whole embryonic mouse brain, with highest expression in telencephalon, whereas SphK2 expression was ubiquitous and highest in limb buds, eyes, and branchial arches. As in vascular development, the $\mathrm{S}_{1} \mathrm{P}_{1}$ receptor was found to be required for normal neural development (Mizugishi et al. 2005).

SphKs furthermore play an important role in cancer growth and survival. SphK1 promotes cancer cell growth, enhances survival of chemotherapy-challenged cells, and stimulates or inhibits cancer cell motility (Hait et al. 2006). In contrast, SphK2 enhances apoptosis, and this effect has been attributed to its BH3 domain (Liu et al. 2003). As other BH3-only proteins, SphK2 interacted directly with the anti-apoptotic $\mathrm{Bcl}-\mathrm{x}_{\mathrm{L}}$, causing its inactivation (Liu et al. 2003). In addition, the catalytic activity and specific subcellular localization contributed to the pro-apoptotic effect of SphK2 (Maceyka et al. 2005). SphK1, on the other hand, increased S1P levels, promoted G1/S transition, and stimulated cell growth when overexpressed in NIH3T3 cells (Olivera et al. 1999). SphK1 overexpression furthermore stimulated colony formation in soft agar and tumor growth in immunodeficient mice, indicating an oncogenic role of SphK1 (Xia et al. 2000). In NIH3T3 cells, SphK activity was specifically enhanced by expression of constitutively active Ras but not Src, whereas Ras-induced focus formation was inhibited by DMS and dominant negative SphK1, placing SphK1 downstream of Ras (Xia et al. 2000). In contrast, VEGF-stimulated Ras activation in bladder carcinoma cells was inhibited by DMS, placing SphK upstream of Ras (Wu et al. 2003). In MCF-7 breast cancer cells, overexpression of SphK1 delayed cell death induced by the anti-cancer drug, doxorubicin, and stimulated estrogen-dependent cell growth and tumor formation in mice (Nava et al. 2002). Estrogen induced a biphasic elevation of SphK activity, and dominant negative SphK1 
inhibited estrogen-dependent growth of MCF-7 cells (Sukocheva et al. 2003). Recently, it was shown that estrogen induced transactivation of EGF receptors in MCF-7 cells via SphK1 and ${\mathrm{S} 1 \mathrm{P}_{3}}_{3}$ (Sukocheva et al. 2006). Downregulation of SphK1 in MCF-7 cells by siRNA caused cell cycle arrest and apoptosis, demonstrating that endogenous SphK1 was required for survival of these cells (Taha et al. 2006c). In prostate cancer cells, overexpression of SphK1 again protected against chemotherapeutics, and siRNA deletion of SphK1 induced apoptosis (Pchejetski et al. 2005). Furthermore, camptothecin and docetaxel induced a strong inhibition of SphK1 in tumor cell lines that were sensitive to these drugs (Pchejetski et al. 2005). SphK1 mRNA levels were elevated in several solid tumors (French et al. 2003). Downregulation of the elevated SphK1 levels in colon adenocarcinomas by siRNA furthermore decreased, and overexpression of SphK1 stimulated, the expression of cyclooxygenase-2, which is a pathogenic factor in colon carcinogenesis (Kawamori et al. 2006). Genetic deletion of SphK1 in a mouse model of intestinal adenomas resulted in suppression of adenoma size but not incidence (Kohno et al. 2006). Not only the growth but also the migration of tumor cells was regulated by SphKs and S1P. The S1P-GPCRs differentially regulate cell migration, with $\mathrm{S}_{1} \mathrm{P}_{1^{-}}$and $\mathrm{S}_{1} \mathrm{P}_{3}$-receptors stimulating and $\mathrm{S}_{1} \mathrm{P}_{2}$-receptors inhibiting migration (Anliker and Chun 2004; Ishii et al. 2004). Therefore, tumor cell motility and invasiveness can be inhibited (Arikawa et al. 2003) or stimulated (Döll et al. 2005; Hait et al. 2005) by SphK or S1P, depending on the S1P-GPCR expression profile. For suppression of tumor growth and improvement of chemosensitivity, SphK inhibitors have been suggested (French et al. 2003, 2006). Furthermore, a monoclonal anti-S1P antibody was recently described that substantially reduced tumor progression in several murine xenograft and allograft models (Visentin et al. 2006). Not only anti-proliferative but also anti-angiogenic effects contributed to tumor growth inhibition by the anti-S1P antibody (Visentin et al. 2006).

S1P is an important mediator in the cardiovascular system (for review, see Alewijnse et al. 2004; Hla 2004). $\mathrm{S} 1 \mathrm{P}$ is an important survival factor for vascular endothelial cells, induces the expression of endothelial cell surface molecules, and controls vascular permeability (Hla 2004). By differential interaction with endothelium and smooth muscle, S1P can cause vasoconstriction or relaxation (Alewijnse et al. 2004; Hla 2004; Watterson et al. 2005; Hemmings 2006). The $\mathrm{S}_{1} \mathrm{P}_{1}$ receptor is essential for blood vessel maturation, whereas the $\mathrm{S}_{1} \mathrm{P}_{3}$ receptor mediates NO production (Nofer et al. 2004; Tölle et al. 2005) and activation of $\mathrm{I}_{\mathrm{K} . \mathrm{ACh}}$ by S1P and FTY720-phosphate (Himmel et al. 2000; Sanna et al. 2004; Forrest et al. 2004).
SphKs are involved in the control of vascular tone. The resting tone of resistance arteries was enhanced by overexpression of SphK1 and decreased by expression of dominant negative SphK1 (Bolz et al. 2003). Similarly, $\left[\mathrm{Ca}^{2+}\right]_{\mathrm{i}}$ increases and vasoconstriction in response to elevated pressure were enhanced by SphK1 overexpression and reduced by dominant-negative SphK1 (Bolz et al. 2003; Keller et al. 2006). Extracellular S1P mimicked the effect of SphK1 overexpression and elevated pressure induced a translocation of SphK1 from the cytosol to the membrane, suggesting that signaling inside-out takes place in this system (Bolz et al. 2003; Keller et al. 2006). SphK was furthermore involved in endothelium-dependent vasorelaxation mediated by $\mathrm{G}_{\mathrm{q}}$-coupled receptors. The contractile response of rat carotid arteries to angiotensin II, but not phenylephrine or $\mathrm{KCl}$ depolarization, was enhanced by the SphK inhibitor, DMS, in an endothelium-dependent manner (Mulders et al. 2006). Furthermore, angiotensin II-stimulated NO release in endothelial cells was inhibited by DMS and a $\mathrm{S}_{1 / 3}$ receptor antagonist, indicating the involvement of SphK and inside-out signaling in angiotensin IIstimulated NO release and vasorelaxation (Mulders et al. 2006). This is in agreement with previous reports showing that extracellular S1P stimulated endothelial NO synthase (Igarashi et al. 2001; Nofer et al. 2004). Acetylcholineinduced vasorelaxation of precontracted rat aortic rings was reduced by the SphK inhibitor, threo-DHS (Roviezzo et al. 2006). Extracellular S1P again imitated the effect, but relaxation by S1P was PTX-sensitive, whereas that by acetylcholine was not. Furthermore, threo-DHS also inhibited vasorelaxation by extracellular S1P, and it was concluded that not S1P-GPCR but intracellular S1P mediated the effect (Roviezzo et al. 2006). The data are in agreement with the previously reported involvement of SphKs in $\mathrm{Ca}^{2+}$ signaling by $\mathrm{M}_{2}$ and $\mathrm{M}_{3}$ receptors (Meyer zu Heringdorf et al. 1998).

TNF- $\alpha$, a key pro-inflammatory cytokine acting on the endothelium, stimulated SphK activity and S1P production in endothelial cells, and SphK inhibition reduced TNF- $\alpha$ stimulated expression of adhesion molecules (E-selectin and vascular adhesion molecule-1; Xia et al. 1998). TNF- $\alpha$ induced SphK activation was independent on sphingomyelinase and ceramidase activities (Xia et al. 1998). Other authors reported that TNF- $\alpha$-stimulated NO synthase in endothelial cells was dependent on a sequential activation of neutral sphingomyelinase-2 and SphK1 (De Palma et al. 2006). NO production by both TNF- $\alpha$ and extracellular S1P were sensitive to PTX, and the effect of TNF- $\alpha$ was abolished by combined antisense to $\mathrm{S}_{1} \mathrm{P}_{1}$ and $\mathrm{S} 1 \mathrm{P}_{3}$ receptors, indicating inside-out signaling (De Palma et al. 2006). Furthermore, TNF- $\alpha$ stimulated the adhesion of immature dendritic cells to endothelial cells, and expression of dominant negative SphK1 or NO synthase inhibition 
enhanced this effect, indicating a negative regulation of pro-inflammatory functions by the SphK/NO synthase pathway (De Palma et al. 2006), in contrast to the previous studies (Xia et al. 1998). A pro-inflammatory role for SphK in the endothelium was recently observed in hyperglycemia. High glucose levels upregulated SphK1 activity in rat aorta and heart, and SphK downregulation attenuated the endothelial expression of proinflammatory adhesion molecules and adhesion of leukocytes to endothelial cells (Wang et al. 2005).

\section{Conclusions}

Many actions have been ascribed to S1P, and SphKs have been identified as important players in the regulation of extracellular as well as intracellular S1P levels. However, the regulation of subcellular pools of S1P by the interplay of SphKs and S1P lyase/phosphatases clearly requires further analysis. Furthermore, the regulation of enzymes such as ceramidases, ceramide synthases, and ceramide kinase that drive the interconversion of S1P, sphingosine, ceramide, and ceramide-1-phosphate, are largely unknown. Several data show how SphK1 can be regulated at the molecular level, but the specific control of SphK1 activity and localization, for example by GPCRs, still remains not fully clear. Much less is even known about regulation of SphK2. One of the most important questions at present, however, might be whether there are other SphK isoforms. By functional studies using subcellular fractionation and diverse assay conditions, three diverse SphK activities were differentiated, all of which were inhibited by DMS (Gijsbers et al. 2001). Although S1P levels in SphK1/2 double knockout mice embryos were not detectable, it cannot be excluded that expression of an additional SphK (s) might occur later during development. Searching for other SphK isoforms has already led to the discovery of a novel enzyme, a monoacylglycerol kinase that is related to SphKs and ceramide kinase (Bektas et al. 2005). It may be evident from this review that even after decades of research, SphKs still remain enigmatic.

\section{References}

Alemany R, Meyer zu Heringdorf D, van Koppen CJ, Jakobs KH (1999) Formyl peptide receptor signaling in HL-60 cells through sphingosine kinase. J Biol Chem 274:3994-3999

Alemany R, Sichelschmidt B, Meyer zu Heringdorf D, Lass H, van Koppen CJ, Jakobs KH (2000) Stimulation of sphingosine-1phosphate formation by the $\mathrm{P} 2 \mathrm{Y}_{2}$ receptor in HL-60 cells: $\mathrm{Ca}^{2+}$ requirement and implication in receptor-mediated $\mathrm{Ca}^{2+}$ mobilization, but not MAP kinase activation. Mol Pharmacol 58:491497
Alemany R, Kleuser B, Ruwisch L, Danneberg K, Lass H, Hashemi R, Spiegel S, Jakobs KH, Meyer zu Heringdorf D (2001) Depolarisation induces rapid and transient formation of intracellular sphingosine-1-phosphate. FEBS Lett 509:239-244

Alewijnse AE, Peters SL, Michel MC (2004) Cardiovascular effects of sphingosine-1-phosphate and other sphingomyelin metabolites. Br J Pharmacol 143:666-684

Allende ML, Proia RL (2002) Sphingosine-1-phosphate receptors and the development of the vascular system. Biochim Biophys Acta 1582:222-227

Allende ML, Sasaki T, Kawai H, Olivera A, Mi Y, Echten-Deckert G, Hajdu R, Rosenbach M, Keohane CA, Mandala S, Spiegel S, Proia RL (2004) Mice deficient in sphingosine kinase 1 are rendered lymphopenic by FTY720. J Biol Chem 279:5248752492

Ancellin N, Colmont C, Su J, Li Q, Mittereder N, Chae SS, Stefansson S, Liau G, Hla T (2002) Extracellular export of sphingosine kinase-1 enzyme. Sphingosine 1-phosphate generation and the induction of angiogenic vascular maturation. J Biol Chem 277:6667-6675

Anliker B, Chun J (2004) Lysophospholipid G protein-coupled receptors. J Biol Chem 279:20555-20558

Arikawa K, Takuwa N, Yamaguchi H, Sugimoto N, Kitayama J, Nagawa H, Takehara K, Takuwa Y (2003) Ligand-dependent inhibition of B16 melanoma cell migration and invasion via endogenous $\mathrm{S}_{1} \mathrm{P}_{2} \mathrm{G}$ protein-coupled receptor. Requirement of inhibition of cellular Rac activity. J Biol Chem 278:32841-32851

Bektas M, Payne SG, Liu H, Goparaju S, Milstien S, Spiegel S (2005) A novel acylglycerol kinase that produces lysophosphatidic acid modulates cross talk with EGFR in prostate cancer cells. J Cell Biol 169:801-811

Billich A, Bornancin F, Devay P, Mechtcheriakova D, Urtz N, Baumruker T (2003) Phosphorylation of the immunomodulatory drug FTY720 by sphingosine kinases. J Biol Chem 278:4740847415

Bolz SS, Vogel L, Sollinger D, Derwand R, Boer C, Pitson SM, Spiegel S, Pohl U (2003) Sphingosine kinase modulates microvascular tone and myogenic responses through activation of RhoA/Rho kinase. Circulation 108:342-347

Brindley DN (2004) Lipid phosphate phosphatases and related proteins: signaling functions in development, cell division, and cancer. J Cell Biochem 92:900-912

Brinkmann V, Cyster JG, Hla T (2004) FTY720: sphingosine 1phosphate receptor-1 in the control of lymphocyte egress and endothelial barrier function. Am J Transplant 4:1019-1025

Chalfant CE, Spiegel S (2005) Sphingosine 1-phosphate and ceramide 1-phosphate: expanding roles in cell signaling. J Cell Sci 118:4605-4612

Chun J, Goetzl EJ, Hla T, Igarashi Y, Lynch KR, Moolenaar W, Pyne S, Tigyi G (2002) International Union of Pharmacology. XXXIV. Lysophospholipid receptor nomenclature. Pharmacol Rev 54:265-269

Clair T, Aoki J, Koh E, Bandle RW, Nam SW, Ptaszynska MM, Mills GB, Schiffmann E, Liotta LA, Stracke ML (2003) Autotaxin hydrolyzes sphingosylphosphorylcholine to produce the regulator of migration, sphingosine-1-phosphate. Cancer Res 63:54465453

De Palma C, Meacci E, Perrotta C, Bruni P, Clementi E (2006) Endothelial nitric oxide synthase activation by tumor necrosis factor $\alpha$ through neutral sphingomyelinase 2, sphingosine kinase 1 , and sphingosine 1 phosphate receptors: a novel pathway relevant to the pathophysiology of endothelium. Arterioscler Thromb Vasc Biol 26:99-105

Delon C, Manifava M, Wood E, Thompson D, Krugmann S, Pyne S, Ktistakis NT (2004) Sphingosine kinase 1 is an intracellular effector of phosphatidic acid. J Biol Chem 279:44763-44774 
Döll F, Pfeilschifter J, Huwiler A (2005) The epidermal growth factor stimulates sphingosine kinase-1 expression and activity in the human mammary carcinoma cell line MCF7. Biochim Biophys Acta 1738:72-81

Duan HF, Qu CK, Zhang QW, Yu WM, Wang H, Wu CT, Wang LS (2006) Shp-2 tyrosine phosphatase is required for hepatocyte growth factor-induced activation of sphingosine kinase and migration in embryonic fibroblasts. Cell Signal 18:20492055

El Shewy HM, Johnson KR, Lee MH, Jaffa AA, Obeid LM, Luttrell LM (2006) Insulin-like growth factors mediate heterotrimeric G protein-dependent ERK1/2 activation by transactivating sphingosine 1-phosphate receptors. J Biol Chem 281:31399-31407

Forrest M, Sun SY, Hajdu R, Bergstrom J, Card D, Doherty G, Hale J, Keohane C, Meyers C, Milligan J, Mills S, Nomura N, Rosen H, Rosenbach M, Shei GJ, Singer II, Tian M, West S, White V, Xie J, Proia RL, Mandala S (2004) Immune cell regulation and cardiovascular effects of sphingosine 1-phosphate receptor agonists in rodents are mediated via distinct receptor subtypes. J Pharmacol Exp Ther 309:758-768

French KJ, Schrecengost RS, Lee BD, Zhuang Y, Smith SN, Eberly JL, Yun JK, Smith CD (2003) Discovery and evaluation of inhibitors of human sphingosine kinase. Cancer Res 63:59625969

French KJ, Upson JJ, Keller SN, Zhuang Y, Yun JK, Smith CD (2006) Antitumor activity of sphingosine kinase inhibitors. J Pharmacol Exp Ther 318:596-603

Fukuda Y, Kihara A, Igarashi Y (2003) Distribution of sphingosine kinase activity in mouse tissues: contribution of SPHK1. Biochem Biophys Res Commun 309:155-160

Futerman AH, Riezman H (2005) The ins and outs of sphingolipid synthesis. Trends Cell Biol 15:312-318

Gijsbers S, Van der Hoeven G, van Veldhoven PP (2001) Subcellular study of sphingoid base phosphorylation in rat tissues: evidence for multiple sphingosine kinases. Biochim Biophys Acta 1532:37-50

Hait NC, Sarkar S, Le Stunff H, Mikami A, Maceyka M, Milstien S, Spiegel S (2005) Role of sphingosine kinase 2 in cell migration toward epidermal growth factor. J Biol Chem 280:2946229469

Hait NC, Oskeritzian CA, Paugh SW, Milstien S, Spiegel S (2006) Sphingosine kinases, sphingosine 1-phosphate, apoptosis and diseases. Biochim Biophys Acta 1758:2016-2026

Hannun YA, Obeid LM (2002) The ceramide-centric universe of lipidmediated cell regulation: Stress encounters of the lipid kind. J Biol Chem 277:25847-25850

Hannun YA, Luberto C, Argraves KM (2001) Enzymes of sphingolipid metabolism: from modular to integrative signaling. Biochemistry 40:4893-4903

Hemmings DG (2006) Signal transduction underlying the vascular effects of sphingosine 1-phosphate and sphingosylphosphorylcholine. Naunyn-Schmiedeberg's Arch Pharmacol 373:18-29

Himmel HM, Meyer zu Heringdorf D, Graf E, Dobrev D, Kortner A, Schüler S, Jakobs KH, Ravens U (2000) Evidence for Edg-3 receptor-mediated activation of $\mathrm{I}_{\mathrm{K} . \mathrm{ACh}}$ by sphingosine-1-phosphate in human atrial cardiomyocytes. Mol Pharmacol 58:449454

Hla T (2004) Physiological and pathological actions of sphingosine 1phosphate. Semin Cell Dev Biol 15:513-520

Hobson JP, Rosenfeldt HM, Barak LS, Olivera A, Poulton S, Caron MG, Milstien S, Spiegel S (2001) Role of the sphingosine-1phosphate receptor EDG-1 in PDGF-induced cell motility. Science 291:1800-1803

Huwiler A, Döll F, Ren S, Klawitter S, Greening A, Romer I, Bubnova S, Reinsberg L, Pfeilschifter J (2006) Histamine increases sphingosine kinase-1 expression and activity in the human arterial endothelial cell line EA.hy 926 by a PKC- $\alpha$ dependent mechanism. Biochim Biophys Acta 1761:367-376

Igarashi J, Bernier SG, Michel T (2001) Sphingosine 1-phosphate and activation of endothelial nitric-oxide synthase. Differential regulation of Akt and MAP kinase pathways by EDG and bradykinin receptors in vascular endothelial cells. J Biol Chem 276:12420-12426

Igarashi N, Okada T, Hayashi S, Fujita T, Jahangeer S, Nakamura S (2003) Sphingosine kinase 2 is a nuclear protein and inhibits DNA synthesis. J Biol Chem 278:46832-46839

Ikeda M, Kihara A, Igarashi Y (2004) Sphingosine-1-phosphate lyase SPL is an endoplasmic reticulum-resident, integral membrane protein with the pyridoxal 5'-phosphate binding domain exposed to the cytosol. Biochem Biophys Res Commun 325:338-343

Imamura T, Ohgane J, Ito S, Ogawa T, Hattori N, Tanaka S, Shiota K (2001) CpG island of rat sphingosine kinase-1 gene: tissuedependent DNA methylation status and multiple alternative first exons. Genomics 76:117-125

Inagaki Y, Li PY, Wada A, Mitsutake S, Igarashi Y (2003) Identification of functional nuclear export sequences in human sphingosine kinase 1. Biochem Biophys Res Commun 311:168 173

Ishii I, Ye X, Friedman B, Kawamura S, Contos JJ, Kingsbury MA, Yang AH, Zhang G, Brown JH, Chun J (2002) Marked perinatal lethality and cellular signaling deficits in mice null for the two sphingosine 1-phosphate $(\mathrm{S} 1 \mathrm{P})$ receptors, $\mathrm{S}_{1} \mathrm{P}_{2} / \mathrm{LP}_{\mathrm{B} 2} / \mathrm{EDG}-5$ and $\mathrm{S}_{1} \mathrm{P}_{3} / \mathrm{LP}_{\mathrm{B} 3} /$ EDG-3. J Biol Chem 277:25152-25159

Ishii I, Fukushima N, Ye X, Chun J (2004) Lysophospholipid receptors: signaling and biology. Annu Rev Biochem 73:321354

Johnson KR, Becker KP, Facchinetti MM, Hannun YA, Obeid LM (2002) PKC-dependent activation of sphingosine kinase 1 and translocation to the plasma membrane. Extracellular release of sphingosine-1-phosphate induced by phorbol 12-myristate 13acetate (PMA). J Biol Chem 277:35257-35262

Johnson KR, Johnson KY, Becker KP, Bielawski J, Mao C, Obeid LM (2003) Role of human sphingosine-1-phosphate phosphatase 1 in the regulation of intra-and extracellular sphingosine-1-phosphate levels and cell viability. J Biol Chem 278:34541-34547

Jolly PS, Bektas M, Olivera A, Gonzalez-Espinosa C, Proia RL, Rivera J, Milstien S, Spiegel S (2004) Transactivation of sphingosine-1-phosphate receptors by FceRI triggering is required for normal mast cell degranulation and chemotaxis. J Exp Med 199:959-970

Kawamori T, Osta W, Johnson KR, Pettus BJ, Bielawski J, Tanaka T, Wargovich MJ, Reddy BS, Hannun YA, Obeid LM, Zhou D (2006) Sphingosine kinase 1 is up-regulated in colon carcinogenesis. FASEB J 20:386-388

Kee TH, Vit P, Melendez AJ (2005) Sphingosine kinase signalling in immune cells. Clin Exp Pharmacol Physiol 32:153-161

Keller M, Lidington D, Vogel L, Peter BF, Sohn HY, Pagano PJ, Pitson S, Spiegel S, Pohl U, Bolz SS (2006) Sphingosine kinase functionally links elevated transmural pressure and increased reactive oxygen species formation in resistance arteries. FASEB J 20:702-704

Kharel Y, Lee S, Snyder AH, Sheasley-O'Neill SL, Morris MA, Setiady Y, Zhu R, Zigler MA, Burcin TL, Ley K, Tung KS, Engelhard VH, Macdonald TL, Pearson-White S, Lynch KR (2005) Sphingosine kinase 2 is required for modulation of lymphocyte traffic by FTY720. J Biol Chem 280:36865-36872

Kihara A, Anada Y, Igarashi Y (2006) Mouse sphingosine kinase isoforms SPHK1a and SPHK1b differ in enzymatic traits including stability, localization, modification, and oligomerization. J Biol Chem 281:4532-4539

Kobayashi N, Nishi T, Hirata T, Kihara A, Sano T, Igarashi Y, Yamaguchi A (2006) Sphingosine 1-phosphate is released from 
the cytosol of rat platelets in a carrier-mediated manner. J Lipid Res 47:614-621

Kohama T, Olivera A, Edsall L, Nagiec MM, Dickson R, Spiegel S (1998) Molecular cloning and functional characterization of murine sphingosine kinase. J Biol Chem 273:23722-23728

Kohno M, Momoi M, Oo ML, Paik JH, Lee YM, Venkataraman K, Ai Y, Ristimaki AP, Fyrst H, Sano H, Rosenberg D, Saba JD, Proia RL, Hla T (2006) Intracellular role for sphingosine kinase 1 in intestinal adenoma cell proliferation. Mol Cell Biol 26:7211-7223

Liu H, Sugiura M, Nava VE, Edsall LC, Kono K, Poulton S, Milstien S, Kohama T, Spiegel S (2000a) Molecular cloning and functional characterization of a novel mammalian sphingosine kinase type 2 isoform. J Biol Chem 275:19513-19520

Liu Y, Wada R, Yamashita T, Mi Y, Deng CX, Hobson JP, Rosenfeldt HM, Nava VE, Chae SS, Lee M-J, Liu CH, Hla T, Spiegel S, Proia RL (2000b) Edg-1, the G protein-coupled receptor for sphingosine-1-phosphate, is essential for vascular maturation. J Clin Invest 106:951-961

Liu H, Toman RE, Goparaju S, Maceyka M, Nava VE, Sankala H, Payne SG, Bektas M, Ishii I, Chun J, Milstien S, Spiegel S (2003) Sphingosine kinase type 2 is a putative $\mathrm{BH} 3$-Only protein that induces apoptosis. J Biol Chem 278:40330-40336

Maceyka M, Payne SG, Milstien S, Spiegel S (2002) Sphingosine kinase, sphingosine-1-phosphate, and apoptosis. Biochim Biophys Acta 1585:193-201

Maceyka M, Sankala H, Hait NC, Le Stunff H, Liu H, Toman R, Collier C, Zhang M, Satin LS, Merrill AH Jr., Milstien S, Spiegel S (2005) SphK1 and SphK2, sphingosine kinase isoenzymes with opposing functions in sphingolipid metabolism. J Biol Chem 280:37118-37129

Malik ZA, Thompson CR, Hashimi S, Porter B, Iyer SS, Kusner DJ (2003) Cutting edge: Mycobacterium tuberculosis blocks $\mathrm{Ca}^{2+}$ signaling and phagosome maturation in human macrophages via specific inhibition of sphingosine kinase. J Immunol 170:28112815

Mandala SM, Thornton R, Galve-Roperh I, Poulton S, Peterson C, Olivera A, Bergstrom J, Kurtz MB, Spiegel S (2000) Molecular cloning and characterization of a lipid phosphohydrolase that degrades sphingosine-1-phosphate and induces cell death. Proc Natl Acad Sci USA 97:7859-7864

Manggau M, Kim DS, Ruwisch L, Vogler R, Korting HC, Schäfer-Korting M, Kleuser B (2001) 1 $\alpha, 25$-dihydroxyvitamin D3 protects human keratinocytes from apoptosis by the formation of sphingosine-1-phosphate. $\mathrm{J}$ Invest Dermatol 117:1241-1249

Melendez AJ, Ibrahim FB (2004) Antisense knockdown of sphingosine kinase 1 in human macrophages inhibits $\mathrm{C} 5 \mathrm{a}$ receptordependent signal transduction, $\mathrm{Ca}^{2+}$ signals, enzyme release, cytokine production, and chemotaxis. J Immunol 173:1596-1603

Melendez AJ, Khaw AK (2002) Dichotomy of $\mathrm{Ca}^{2+}$ signals triggered by different phospholipid pathways in antigen stimulation of human mast cells. J Biol Chem 277:17255-17262

Melendez AJ, Carlos-Dias E, Gosink M, Allen JM, Takacs L (2000) Human sphingosine kinase: molecular cloning, functional characterization and tissue distribution. Gene 251:19-26

Meyer zu Heringdorf D (2004) Lysophospholipid receptor-dependent and -independent calcium signaling. J Cell Biochem 92:937-948

Meyer zu Heringdorf D, Jakobs KH (2006) Lysophospholipid receptors: signalling, pharmacology and regulation by lysophospholipid metabolism. Biochim Biophys Acta [Epub ahead of print]

Meyer zu Heringdorf D, Lass H, Alemany R, Laser KT, Neumann E, Zhang C, Schmidt M, Rauen U, Jakobs KH, van Koppen CJ (1998) Sphingosine kinase-mediated $\mathrm{Ca}^{2+}$ signalling by $\mathrm{G}$ protein-coupled receptors. EMBO J 17:2830-2837

Meyer zu Heringdorf D, Liliom K, Schaefer M, Danneberg K, Jaggar JH, Tigyi G, Jakobs KH (2003) Photolysis of intracellular caged sphingosine-1-phosphate causes $\mathrm{Ca}^{2+}$ mobilization independently of G-protein-coupled receptors. FEBS Lett 554:443-449

Michaud J, Kohno M, Proia RL, Hla T (2006) Normal acute and chronic inflammatory responses in sphingosine kinase 1 knockout mice. FEBS Lett 580:4607-4612

Mitra P, Oskeritzian CA, Payne SG, Beaven MA, Milstien S, Spiegel $S$ (2006) Role of ABCC1 in export of sphingosine-1-phosphate from mast cells. Proc Natl Acad Sci USA 103:16394-16399

Mizugishi K, Yamashita T, Olivera A, Miller GF, Spiegel S, Proia RL (2005) Essential role for sphingosine kinases in neural and vascular development. Mol Cell Biol 25:11113-11121

Mulders AC, Hendriks-Balk MC, Mathy MJ, Michel MC, Alewijnse AE, Peters SL (2006) Sphingosine kinase-dependent activation of endothelial nitric oxide synthase by angiotensin II. Arterioscler Thromb Vasc Biol 26:2043-2048

Nava VE, Lacana E, Poulton S, Liu H, Sugiura M, Kono K, Milstien S, Kohama T, Spiegel S (2000) Functional characterization of human sphingosine kinase-1. FEBS Lett 473:81-84

Nava VE, Hobson JP, Murthy S, Milstien S, Spiegel S (2002) Sphingosine kinase type 1 promotes estrogen-dependent tumorigenesis of breast cancer MCF-7 cells. Exp Cell Res 281:115127

Nofer JR, van der Giet M, Tölle M, Wolinska I, von Wnuck LK, Baba HA, Tietge UJ, Gödecke A, Ishii I, Kleuser B, Schäfers M, Fobker M, Zidek W, Assmann G, Chun J, Levkau B (2004) HDL induces NO-dependent vasorelaxation via the lysophospholipid receptor $\mathrm{S}_{1} \mathrm{P}_{3}$. J Clin Invest 113:569-581

Ogretmen B, Hannun YA (2004) Biologically active sphingolipids in cancer pathogenesis and treatment. Nat Rev Cancer 4:604-616

Okada T, Ding G, Sonoda H, Kajimoto T, Haga Y, Khosrowbeygi A, Gao S, Miwa N, Jahangeer S, Nakamura S (2005) Involvement of N-terminal-extended form of sphingosine kinase 2 in serumdependent regulation of cell proliferation and apoptosis. J Biol Chem 280:36318-36325

Olivera A, Rivera J (2005) Sphingolipids and the balancing of immune cell function: lessons from the mast cell. J Immunol 174:1153-1158

Olivera A, Spiegel S (1993) Sphingosine-1-phosphate as second messenger in cell proliferation induced by PDGF and FCS mitogens. Nature 365:557-560

Olivera A, Rosenthal J, Spiegel S (1996) Effect of acidic phospholipids on sphingosine kinase. J Cell Biochem 60:529-537

Olivera A, Kohama T, Tu Z, Milstien S, Spiegel S (1998) Purification and characterization of rat kidney sphingosine kinase. J Biol Chem 273:12576-12583

Olivera A, Kohama T, Edsall L, Nava V, Cuvillier O, Poulton S, Spiegel S (1999) Sphingosine kinase expression increases intracellular sphingosine-1-phosphate and promotes cell growth and survival. J Cell Biol 147:545-558

Olivera A, Rosenfeldt HM, Bektas M, Wang F, Ishii I, Chun J, Milstien S, Spiegel S (2003) Sphingosine kinase type 1 Induces $\mathrm{G}_{12 / 13}$-mediated stress fiber formation yet promotes growth and survival independent of $\mathrm{G}$ protein coupled receptors. J Biol Chem 278:46452-46460

Olivera A, Urtz N, Mizugishi K, Yamashita Y, Gilfillan AM, Furumoto Y, Gu H, Proia RL, Baumruker T, Rivera J (2006) IgE-dependent activation of sphingosine kinases 1 and 2 and secretion of sphingosine 1-phosphate requires Fyn kinase and contributes to mast cell responses. J Biol Chem 281:2515-2525

Pchejetski D, Golzio M, Bonhoure E, Calvet C, Doumerc N, Garcia V, Mazerolles C, Rischmann P, Teissie J, Malavaud B, Cuvillier O (2005) Sphingosine kinase-1 as a chemotherapy sensor in prostate adenocarcinoma cell and mouse models. Cancer Res 65:11667-11675

Pettus BJ, Bielawska A, Subramanian P, Wijesinghe DS, Maceyka M, Leslie CC, Evans JH, Freiberg J, Roddy P, Hannun YA, Chalfant 
CE (2004) Ceramide 1-phosphate is a direct activator of cytosolic phospholipase A2. J Biol Chem 279:11320-11326

Pitson SM, D'Andrea RJ, Vandeleur L, Moretti PAB, Xia P, Gamble JR (2000a) Human sphingosine kinase: purification, molecular cloning and characterization of the native and recombinant enzymes. Biochem J 350:429-441

Pitson SM, Moretti PAB, Zebol JR, Xia P, Gamble JR, Vadas MA, D'Andrea RJ, Wattenberg BW (2000b) Expression of a catalytically inactive sphingosine kinase mutant blocks agonist-induced sphingosine kinase activation. A dominant-negative sphingosine kinase. J Biol Chem 275:33945-33950

Pitson SM, Moretti PA, Zebol JR, Vadas MA, D’Andrea RJ, Wattenberg BW (2001) A point mutant of human sphingosine kinase 1 with increased catalytic activity. FEBS Lett 509:169-173

Pitson SM, Moretti PA, Zebol JR, Zareie R, Derian CK, Darrow AL, Qi J, D'Andrea RJ, Bagley CJ, Vadas MA, Wattenberg BW (2002) The nucleotide-binding site of human sphingosine kinase 1. J Biol Chem 277:49545-49553

Pitson SM, Moretti PA, Zebol JR, Lynn HE, Xia P, Vadas MA, Wattenberg BW (2003) Activation of sphingosine kinase 1 by ERK1/2-mediated phosphorylation. EMBO J 22:54915500

Pitson SM, Xia P, Leclercq TM, Moretti PA, Zebol JR, Lynn HE, Wattenberg BW, Vadas MA (2005) Phosphorylation-dependent translocation of sphingosine kinase to the plasma membrane drives its oncogenic signalling. J Exp Med 201:49-54

Pyne S, Long JS, Ktistakis NT, Pyne NJ (2005) Lipid phosphate phosphatases and lipid phosphate signalling. Biochem Soc Trans 33:1370-1374

Reiss U, Oskouian B, Zhou J, Gupta V, Sooriyakumaran P, Kelly S, Wang E, Merrill AH Jr., Saba JD (2004) Sphingosine-phosphate lyase enhances stress-induced ceramide generation and apoptosis. J Biol Chem 279:1281-1290

Roviezzo F, Bucci M, Delisle C, Brancaleone V, Di Lorenzo A, Mayo IP, Fiorucci S, Fontana A, Gratton JP, Cirino G (2006) Essential requirement for sphingosine kinase activity in eNOS-dependent NO release and vasorelaxation. FASEB J 20:340-342

Saba JD, Hla T (2004) Point-counterpoint of sphingosine 1-phosphate metabolism. Circ Res 94:724-734

Safadi-Chamberlain F, Wang LP, Payne SG, Lim CU, Stratford S, Chavez JA, Fox MH, Spiegel S, Summers SA (2005) Effect of a membrane-targeted sphingosine kinase 1 on cell proliferation and survival. Biochem J 388:827-834

Sanna MG, Liao J, Jo E, Alfonso C, Ahn MY, Peterson MS, Webb B, Lefebvre S, Chun J, Gray N, Rosen H (2004) Sphingosine 1phosphate $(\mathrm{S} 1 \mathrm{P})$ receptor subtypes $\mathrm{S}_{1} \mathrm{P}_{1}$ and $\mathrm{S}_{1} \mathrm{P}_{3}$, respectively, regulate lymphocyte recirculation and heart rate. J Biol Chem 279:13839-13848

Schwab SR, Pereira JP, Matloubian M, Xu Y, Huang Y, Cyster JG (2005) Lymphocyte sequestration through S1P lyase inhibition and disruption of S1P gradients. Science 309:1735-1739

Snook CF, Jones JA, Hannun YA (2006) Sphingolipid-binding proteins. Biochim Biophys Acta 1761:927-946

Spiegel S, Milstien S (2003) Sphingosine-1-phosphate: An enigmatic signalling lipid. Nat Rev Mol Cell Biol 4:397-407

Stahelin RV, Hwang JH, Kim JH, Park ZY, Johnson KR, Obeid LM, Cho W (2005) The mechanism of membrane targeting of human sphingosine kinase 1. J Biol Chem 280:43030-43038

Sukocheva OA, Wang L, Albanese N, Pitson SM, Vadas MA, Xia P (2003) Sphingosine kinase transmits estrogen signaling in human breast cancer cells. Mol Endocrinol 17:2002-2012

Sukocheva O, Wadham C, Holmes A, Albanese N, Verrier E, Feng F, Bernal A, Derian CK, Ullrich A, Vadas MA, Xia P (2006) Estrogen transactivates EGFR via the sphingosine 1-phosphate receptor Edg-3: the role of sphingosine kinase-1. J Cell Biol $173: 301-310$
Sutherland CM, Moretti PA, Hewitt NM, Bagley CJ, Vadas MA, Pitson SM (2006) The calmodulin-binding site of sphingosine kinase and its role in agonist-dependent translocation of sphingosine kinase 1 to the plasma membrane. J Biol Chem 281:11693-11701

Taha TA, Kitatani K, Bielawski J, Cho W, Hannun YA, Obeid LM (2005) Tumor necrosis factor induces the loss of sphingosine kinase-1 by a cathepsin B-dependent mechanism. J Biol Chem 280:17196-17202

Taha TA, Hannun YA, Obeid LM (2006a) Sphingosine kinase: biochemical and cellular regulation and role in disease. $\mathrm{J}$ Biochem Mol Biol 39:113-131

Taha TA, El Alwani M, Hannun YA, Obeid LM (2006b) Sphingosine kinase-1 is cleaved by cathepsin B in vitro: Identification of the initial cleavage sites for the protease. FEBS Lett 580:6047-6054

Taha TA, Kitatani K, El Alwani M, Bielawski J, Hannun YA, Obeid LM (2006c) Loss of sphingosine kinase-1 activates the intrinsic pathway of programmed cell death: modulation of sphingolipid levels and the induction of apoptosis. FASEB J 20:482-484

Thompson CR, Iyer SS, Melrose N, VanOosten R, Johnson K, Pitson SM, Obeid LM, Kusner DJ (2005) Sphingosine kinase 1 (SK1) is recruited to nascent phagosomes in human macrophages: inhibition of SK1 translocation by Mycobacterium tuberculosis. J Immunol 174:3551-3561

Tölle M, Levkau B, Keul P, Brinkmann V, Giebing G, Schonfelder G, Schäfers M, von Wnuck LK, Jankowski J, Jankowski V, Chun J, Zidek W, van der Giet M (2005) Immunomodulator FTY720 Induces eNOS-dependent arterial vasodilatation via the lysophospholipid receptor $\mathrm{S}_{1} \mathrm{P}_{3}$. Circ Res 96:913-920

Toman RE, Payne SG, Watterson KR, Maceyka M, Lee NH, Milstien S, Bigbee JW, Spiegel S (2004) Differential transactivation of sphingosine-1-phosphate receptors modulates NGF-induced neurite extension. J Cell Biol 166:381-392

Venkataraman K, Thangada S, Michaud J, Oo ML, Ai Y, Lee YM, Wu M, Parikh NS, Khan F, Proia RL, Hla T (2006) Extracellular export of sphingosine kinase-1a contributes to the vascular S1P gradient. Biochem J 397:461-471

Visentin B, Vekich JA, Sibbald BJ, Cavalli AL, Moreno KM, Matteo RG, Garland WA, Lu Y, Yu S, Hall HS, Kundra V, Mills GB, Sabbadini RA (2006) Validation of an anti-sphingosine-1phosphate antibody as a potential therapeutic in reducing growth, invasion, and angiogenesis in multiple tumor lineages. Cancer Cells 9:225-238

Wang L, Xing XP, Holmes A, Wadham C, Gamble JR, Vadas MA, Xia $P$ (2005) Activation of the sphingosine kinase-signaling pathway by high glucose mediates the proinflammatory phenotype of endothelial cells. Circ Res 97:891-899

Waters CM, Long J, Gorshkova I, Fujiwara Y, Connell M, Belmonte KE, Tigyi G, Natarajan V, Pyne S, Pyne NJ (2006) Cell migration activated by platelet-derived growth factor receptor is blocked by an inverse agonist of the sphingosine 1-phosphate receptor-1. FASEB J 20:509-511

Wattenberg BW, Pitson SM, Raben DM (2006) The sphingosine and diacylglycerol kinase superfamily of signaling kinases: localization as a key to signaling function. J Lipid Res 47:1128-1139

Watterson KR, Ratz PH, Spiegel S (2005) The role of sphingosine-1phosphate in smooth muscle contraction. Cell Signal 17:289-298

Wu W, Shu X, Hovsepyan H, Mosteller RD, Broek D (2003) VEGF receptor expression and signaling in human bladder tumors. Oncogene 22:3361-3370

Xia P, Gamble JR, Rye K-A, Wang L, Hii CST, Cockerill P, KhewGoodall Y, Bert AG, Barter PJ, Vadas MA (1998) Tumor necrosis factor- $\alpha$ induces adhesion molecule expression through the sphingosine kinase pathway. Proc Natl Acad Sci USA 95:14196-14201 
Xia P, Gamble JR, Wang L, Pitson SM, Moretti PAB, Wattenberg BW, D'Andrea RJ, Vadas MA (2000) An oncogenic role of sphingosine kinase. Curr Biol 10:1527-1530

Xia P, Wang L, Moretti PA, Albanese N, Chai F, Pitson SM, D’Andrea RJ, Gamble JR, Vadas MA (2002) Sphingosine kinase interacts with TRAF2 and dissects tumor necrosis factor-alpha signaling. J Biol Chem 277:7996-8003

Yokota S, Taniguchi Y, Kihara A, Mitsutake S, Igarashi Y (2004) Asp177 in C4 domain of mouse sphingosine kinase 1a is important for the sphingosine recognition. FEBS Lett 578:106-110

Yoshimoto T, Furuhata M, Kamiya S, Hisada M, Miyaji H, Magami Y, Yamamoto K, Fujiwara H, Mizuguchi J (2003) Positive modulation of IL-12 signaling by sphingosine kinase 2 associating with the IL-12 receptor beta 1 cytoplasmic region. J Immunol 171:1352-1359
Young KW, Nahorski SR (2001) Intracellular sphingosine 1-phosphate production: a novel pathway for $\mathrm{Ca}^{2+}$ release. Semin Cell Dev Biol 12:19-25

Young KW, Willets JM, Parkinson MJ, Bartlett P, Spiegel S, Nahorski SR, Challiss RA (2003) $\mathrm{Ca}^{2+} /$ calmodulin-dependent translocation of sphingosine kinase: role in plasma membrane relocation but not activation. Cell Calcium 33:119-128

Zemann B, Kinzel B, Müller M, Reuschel R, Mechtcheriakova D, Urtz N, Bornancin F, Baumruker T, Billich A (2006) Sphingosine kinase type 2 is essential for lymphopenia induced by the immunomodulatory drug FTY720. Blood 107:1454-1458

Zhang H, Desai NN, Olivera A, Seki T, Brooker G, Spiegel S (1991) Sphingosine-1-phosphate, a novel lipid, involved in cellular proliferation. J Cell Biol 114:155-167 